\title{
THE DURHAM RULE AND JUDICIAL ADMINISTRATION OF THE INSANITY DEFENSE IN THE DISTRICT OF COLUMBIA
}

\author{
ABE KRASH广
}

ON July 1, 1954, in Durham v. United States, ${ }^{1}$ the United States Court of Appeals for the District of Columbia Circuit announced a new test of responsibility to be applied in all future criminal cases in the District: "[A]n accused is not criminally responsible if his unlawful act was the product of mental disease or defect."' This new standard was designed to reconcile the rule of responsibility with advances in medical knowledge, and to broaden the class of persons who would be treated instead of punished; more particularly, it was framed to facilitate communication between psychiatric experts and the courts which was being impeded by the pre-existing tests. Although the Durham decision has provoked extensive discussion ${ }^{3}$-indeed, one commentator has observed that "Probably no criminal case of the past decade has been the subject of such widespread debate"4-the Durham formula has been adopted in only one other jurisdiction. ${ }^{5}$ While the test has been warmly endorsed by

$\dagger$ Member of the District of Columbia Bar.

I am greatly indebted for many helpful comments in connection with an earlier draft of this article to my colleague, Abe Fortas; Professor Abraham Goldstein of the Yale Law School; and Mrs. Howard Adler, a member of the Indiana bar.

1. 214 F.2d 862 (D.C. Cir. 1954).

2. Id. at $874-75$.

3. The literature on the Durham rule has attained formidable proportions. See, e.g., Insanity and the Criminal Lau-A Critique of Durham v. United States, 22 U. CHI. L. Rev. 317 (1955); Sobeloff, Insanity and the Criminal Law: From McNaghten to Durham and Beyond, 41 A.B.A.J. 793 (1955); Arnold, Due Process in Trials, 300 Annals 123 (1955); Hall, Psychiatry and Criminal Responsibility, 65 YALE L.J. 761 (1956) ; Dotglas, The Durham Rule: A Meeting Ground for Lawyers and Psychiatrists, 41 Iowa L. Rev. 485 (1956) ; Note, 58 Colum. L. Rev. 1253 (1958); Szasz, Psychiatry, Ethics, and the Criminal Law, 58 Colum. L. Rev. 183 (1958) ; Symposium, Mental Disease and Criminal Responsibility, 5 Catriolic Law. 3 (1959); Watson, Durham Plus Five Years: Development of the Law of Criminal Responsibility in the District of Columbia, 116 Ans. J. PsyCHINTRY 289 (1959); Report of Committee on Criminal Responsibility, 26 J.D.C. BAR Ass's 301 (1959); Reid, Understandistg the New Hampshire Doctrine of Criminal Insanity, 69 YALE L.J. 367 (1960) ; Halleck, The Insanity Deferse in the District of Columbia-A Legal Lorelei, 49 Gro. L.J. 294 (1960); Bazelon, The Awesome Decision, Saturday Evening Post, January 23, 1960, p. 32.

4. Weihofen, The "Test" of Criminal Responsibility: Recent Developments, 172 INT'z Recond of Medicine 638 (1959).

5. Sce V.I Code ANN. tit. 14, $\S 1,14$ (1957):

All persons are capable of committing crimes or offenses except-

(4) Persons who are mentally ill and who committed the act charged against them in consequence of such mental illness.

The Durham decision helped to inspire reconsideration of the criminal responsibility stand- 
many psychiatrists ${ }^{6}$ and by some individual judges, ${ }^{7}$ it has not yet won the approval of any other court. ${ }^{8}$

In the seven years which have elapsed since Durham was decided, an elaborate corpus of precedent and practice has evolved in the District of Columbia ranging over nearly every procedural and substantive question that can arise in connection with the insanity problem in criminal cases. The Court of Appeals has issued more than eighty opinions since July 1954 relating to judicial administration of the insanity defense-an astonishing volume unmatched

ard by executive and legislative commissions in a number of states including, among others, New York, see N.Y. Times, July 25, 1959, § E, p. 6E, col. 1; id., July 26, 1959, p. 50, col. 3; id., Aug. 4, 1959, p. 27, col. 8; id., Feb. 13, 1961, p. 29, col. 8; Maryland, see Washington Post \& Times Herald, Feb. 10, 1959, p. B1, col. 6; id., June 14, 1959, p. B8, col. 1; and Massachusetts, see 42 Mass. L.Q. No. 4, 56 (1957).

6. See, e.g., Roche, Criminality and Mental Illucss-Two Faces of the Same Coin, 22 U. CHI. L. Rev. 320 (1955); Guttmacher, The Psychiatrist as an Expert Witness, id. at 325; Zilboorg, A Step Toward Enlightcned Justice, id. at 331.

7. See, e.g., Douglas, supra note 3; Sobeloff, supra note 3; Howard v. United States, 229 F.2d 602, 607 (5th Cir.), rev'd on rehearing en banc, 232 F.2d 274 (1956) (Rives, J., dissenting).

8. The Durham formula has been rejected as a standard by various federal courts. Voss v. United States, 259 F.2d 699 (8th Cir. 1958); Sauer v. United States, 241 F.2d 640 (9th Cir.), cert. denied, 354 U.S. 940 (1957) ; Andersen v. United States, 237 F.2d 118, 127 (9th Cir. 1956) ; Howard v. United States, 229 F.2d 602 (5th Cir.), rev'd on rehearing en banc, 232 F.2d 274 (1956) ; United States v. Hopkins, 169 F. Supp. 187, 189 (D. Md. 1958). See also United States v. Kunak, 5 U.S.C.M.A. 346 (1954); United States v. Smith, 5 U.S.C.M.A. 314 (1954).

The courts of twenty-two states have declined to follow Durham. Arizuna: State v. Crose, 357 P.2d 136 (Ariz. 1960); Arkansas: Downs v. State, 330 S.W.2d 281 (Ark. 1959); California: People v. Ryan, 140 Cal. App. 2d 412, 425, 295 P.2d 496, 504 (Dist. Ct. App. 1956); Colorado: Early v. People, 352 P.2d 112 (Colo. 1960); Connecticut: State v. Davies, 146 Conn. 137, 145-49, 148 A.2d 251, 255-57 (1959), cert. denied, 360 U.S. 921 (1959) ; Florida: Picott v. State, 116 So. $2 d 626$ (Fla. 1959); Illinois: People v. Carpenter, 11 Ill. 2d 60, 64-68, 142 N.E.2d 11, 13-15 (1957) ; Indiana: Flowers v. State, 236 Ind. 151, 139 N.E.2d 185 (1956) ; Kansas: State v. Andrews, 357 P.2d 739 (Kan. 1960); Maryland: Cole v. State, 212 Md. 55, 128 A.2d 437 (1957) ; Bryant v. State, 207 Md. 565, 115 A.2d 502 (1955) ; Thomas v. State, 206 Md. 575, 112 A.2d 913 (1955) ; Massachusetts: Commonwealth v. Chester, 337 Mass. 702, 712-13, 150 N.E.2d 914, 919-20 (1958); Minnesota: State v. Finn, 100.N.W.2d 508 (Minn. 1960); Missouri: State v. Goza, 317 S.W.2d 609 (Mo. 1958) ; Montana: State v. Kitchens, 129 Mont. 331, 337, 286 P.2d 1079, 1082 (1955); Nevada: Sollars v. State, 73 Nev.248, 316 P.2d 917. (1957) ; New Jersey: State v. Lucas, 30 N.J. 37, 63-72, 152 A.2d 50, 64-69 (1959); Nezw York: People.v. Johnson, 169 N.Y.S. $2 \mathrm{~d} 217$ (Westchester County Ct. 1957) ; Ohio ; State v. Robinson, 168 N.E.2d 328 (Ohio Ct. App. 1958); Penusylvania : Commonwealth $v$, Novak, 395 Pa. 199, 150 A:2d 102 (1959); Commonwealth v. Woodhouse, 164 A.2d 98 (Pa. 1960); Utah: State v. Kirkham, 7 Utah 2d 108, 319 P.2d 859 (1958); Vermont: State v. Goyet, 120 Vt. 12, 54-61, 132 A.2d 623, 650-54 (1957); Washington: State v. Collins, 50 Wash. 2d 740, 749-55, 314 P.2d 660, 66568 (1957). But cf. Anderson v. Grasberg, 247 Minn. 538, 555, 78 N.W.2d 450, 461 (1956) (Durham rule applied in a civil case in a jurisdiction which follows MPNaghten rule in criminal cases). 
by any other federal or state court. ${ }^{9}$ While the merits of the Durham test itself have been widely argued, these subsequent opinions have not received equivalent attention, ${ }^{10}$ although they are significant even for jurisdictions which have rejected Durham as a standard of responsibility.

The new substantive rule of law promulgated in Durham provides a fresh standard for assessing the defendant's responsibility as of the time of the alleged offense. The Durham rule is designed to be applied at the trial itself. It regulates the presentation of evidence as to mental disorder; it is the standard of reference for medical experts and laymen who testify with respect to the accused's mental condition; and it is the test which the trial judge directs the jury to apply.

Like any other substantive rule, however, Durham is profoundly influenced by its setting in the litigation process. For example, the mental condition of the accused may have been drawn in issue long before trial by a plea that the defendant is not competent to stand trial. The Durham test is technically irrelevant to the question of the defendant's fitness to stand trial. But the test for deternining capacity to stand trial-whether a defendant is so mentally incompetent "as to be unable to understand the proceedings against him or properly to assist in his own defense"11_-is intimately related in practice to the Durham rule. Thus, the psychiatric examination, which is designed to assist the court in determining whether the defendant is competent to stand trial, may also encompass an investigation into whether the defendant was mentally diseased as of the date of the offense. ${ }^{12}$ The psychiatric experts who examine the accused in connection with pretrial competency proceedings are, therefore, frequently called as witnesses to testify at the trial concerning the accused's mental condition at the time of the offense.

Similarly, the application of the Durham rule is affected in practice by problems concerning a defendant's mental condition which can arise subsequent to trial. A defendant in the District who is found not guilty by reason of insanity is automatically hospitalized in a mental institution. ${ }^{13}$ In order to be

9. The United States District Court in the District of Columbia is vested with general jurisdiction over "all crimes and offenses" committed within the District. D.C. CODE ANN. $\$ 11-306$ (1952). Its jurisdiction thus extends to cases of a kind normally tried in state courts, e.g., prosecutions for homicide, assault, larceny, etc., as well as to federal criminal offenses. The D.C. Court of Appeals exercises appellate jurisdiction over all final judgments of the District Court, 28 U.S.C. $\$ 1291$ (1958), so that its appellate jurisdiction in criminal cases is analogous in many respects to that of a state supreme court.

10. For a discussion of some post-Durham developments see Goldstein \& Katz, Dangerousness and Mental Illness: Sonte Observations on the Decision to Release. Persons Acquitted by Reason of Insanity, 70 Yale L.J. 225 (1960); Gasch, Prosecution Problems Under the Durham Rule, 5 Catholic Law. 5 (1959); Note, 58 Colum. L. Rev. 1253 (1958).

11. D.C. Code ANn. \$24-301 (a) (Supp. VIII, 1960). The test of competence to stand trial is the same in all other federal courts. 18 U.S.C. $\$ 4244$ (1958).

12. Winn v. United States, 270 F.2d 326 (D.C. Cir. 1959).

13. D.C. Code AnN. \& 24-301(d) (Supp. VIII, 1960). See note 188 infra and accompanying text. 
released from hospital confinement, he must demonstrate that he has recovered his sanity and that he will not be dangerous to himself or others. ${ }^{14}$ Although this release formula is phrased differently from the Durham rule, the two tests are, again, intimately intertwined in practice. To cite but one example, strict enforcement of the standard governing release has affected the willingness of some defendants to invoke the Durham defense.

In short, the Durham rule has made a sharp impact on pretrial competency and posttrial release proceedings. Administration of the Durham test itself has, in turn, been deeply influenced by questions that arise in connection with fitness to stand trial and discharge.

This article discusses some of the issues that have arisen in the District of Columbia in the post-Durham years in connection with judicial administration of the three different tests governing competence to stand trial, responsibility, and release, ${ }^{15}$ and the interrelationship of these standards. ${ }^{16}$ These problems are not unique to the District of Columbia. Any jurisdiction which recognizes insanity as a defense must resolve such questions as competence to stand trial, the proper scope of psychiatric testimony, and the disposition that should be made of a defendant acquitted by reason of insanity. The experience in the District of Columbia is particularly illuminating, however, since in the past seven years many of the issues associated with the problems of mental disorder in criminal cases have received careful consideration in the light of a new and far-reaching test of criminal responsibility.

\section{Pretrial Issues: Competence to Stand Trial}

The universally accepted rule prohibiting the trial of a mentaily incompetent defendant ${ }^{\mathbf{1 7}}$ rests, in part, upon humane considerations; in part, upon the view that the judicial process would be denigrated by the spectacle of a prosecution of a severely disoriented person; and, perhaps most basically, upon the realization that the reliability of a conviction is reduced if individuals incapable of self-defense are forced to stand trial.

In the District of Columbia, the governing statute ${ }^{18}$ provides that a motion for a psychiatric examination to determine competence to stand trial must

14. D.C. Code Ann. $\$ 24-301$ (e) (Supp. VIII, 1960); see Overholser v. Leach, 257 F.2d 667 (D.C. Cir. 1958), cert. denied, 359 U.S. 1013 (1959).

15. See Lyles v. United States, 254 F.2d 725, 729-30 (D.C. Cir. 1957), cert. denicd, 356 U.S. 961 (1958) (Prettyman and Burger, JJ.); Overholser v. Leach, 257 F.2d 667, 670 n.4 (D.C. Cir. 1958), cert. denied, 359 U.S. 1013 (1959).

16. Issues relating to insanity in civil proceedings in the District of Columbia are beyond the scope of this article. See Dooling v. Overholser, 243 F.2d 825 (D.C. Cir. 1957); Katims, Procedures for Adjudication in Non-Criminal Mental Health Cases in the District of Columbia, 25 J.D.C. BAR Ass'N 294 (1958).

17. See Model Penal Cone $\S 4.04$, comment (Tent. Draft No. 4, 1955). It has been held that the trial of an incompetent person would violate due process. Overholser v. Lynch, No. 15,859, D.C. Cir., January 26, 1961.

18. D.C. CoDE ANN. $\$ 24-301$ (a) (Supp. VIII, 1960). 
he supported by "prima facie evidence . . . that the accused is of unsound mind or is [so] mentally incompetent ... as to be unable to understand the proceedings against him or properly to assist in his own defense."10 If the motion is granted, or if the court so orders on its own initiative, ${ }^{20}$ the defendant may be committed to a mental hospital for a "reasonable period" for "examination and observation and for care or treatment." If the hospital authorities report to the court that "the accused is of unsound mind or mentally incompetent," the court may, without more, order the defendant committed to a mental institution. In the event of objection, however, the court is required to conduct a hearing and to make "a judicial determination of the competency of the accused to stand trial." A defendant found incompetent is committed to a mental institution until the hospital superintendent certifies to the court that the accused has been "restored to mental competency." 21 On the basis of such certification, the court may enter an order that the defendant is fit to stand trial, but if the prosecution or the defense objects, the court must conduct a hearing to determine if the defendant is competent to stand trial. ${ }^{22} \mathrm{~A}$ defendant who is adjudged mentally competent is brought to trial.

A number of thorny questions have emerged in connection with the foregoing procedures. Should a psychiatric examination to determine competence to stand trial also embrace an inquiry into the accused's mental condition as of the time of the offense? Is it sufficient for psychiatrists to report their findings in the conclusory language of the statute, or should detailed underlying findings be submitted by them to the court? And what should be done in the event that an accused person refuses to be interviewed by psychiatrists?

\section{The Motion for a Pretrial Mental Examination}

The District of Columbia is unique in requiring that a motion for a psychiatric examination must be supported by "prima facie" evidence that the defendant is of unsound mind. ${ }^{23}$ When the Durham case was decided in 1954, competence to stand trial in the District ${ }^{24}$ was determined on the same basis as in federal courts elsewhere. ${ }^{25}$ Under that procedure, "reasonable cause to believe" that an accused is unfit to stand trial justifies a motion for a psychiatric examination. ${ }^{26}$ In order to make psychiatric examinations more readily available, the D.C. Court of Appeals had construed this provision before Durham

19. Ibid.

20. Cf. Carter v. United States, 283 F.2d 200 (D.C. Cir. 1960).

21. D.C. Code Ans. \& 24-301 (b) (Supp. VIII, 1960).

22. Ibid.

23. Compare the Briggs Act in Massachusetts which provides for an automatic mental exarnination for certain classes of accused persons. MAss. ANN. LAws ch. $123, \S 100 \mathrm{~A}$ (1955) ; see Kreutzer, Re-examination of the Briggs Law, 39 B.U.L. Rev. 188 (1959).

24. See Wear v. United States, 218 F.2d 24 (D.C. Cir. 1954).

25. See Report of Committee to Study Treatment Accorded by Federal Courts to Insane Persons Charged with Crime (1944).

26. 63 Stat. 686 (1949), 18 U.S.C. § 4244 (1958). 
to require a mental examination unless the motion was made in bad faith and the supporting grounds were frivolous. ${ }^{27}$

This ruling was attacked in the District after the Durham case was decided on the ground that it would encourage attempts to avoid punishment. ${ }^{28}$ It was argued that an accused person could engineer his being sent to a mental hospital for a pretrial examination by filing a petition which was not patently frivolous, and that at the trial he could then use the period of hospitalization as evidence to persuade a jury that he suffered from a mental disease or defect at the time of the offense. ${ }^{29}$ This argument prevailed with Congress. In 1955 it provided that in the District of Columbia courts alone a more exacting "prima facie" showing, rather than simply "reasonable cause," would be a jurisdictional prerequisite to a pretrial psychiatric examination."

The "prima facie" evidence requirement is quixotic in a number of respects. In effect, the statute demands a showing at the outset of the very data which the motion is designed to elicit by psychiatric examination. Moreover, the statute was drafted with the objective of making it more difficult to obtain a psychiatric examination, ${ }^{31}$ although the trend, as evidenced by Congressional enactment in 1949 of the "reasonable cause" provision, has been in just the opposite direction. Finally, there is little merit to the argument that a malingerer can mislead a jury by pointing to a history of hospital confinement in connection with a competency inquiry. Under District law, as under federal statute, evidence that the defendant is competent to stand trial is normally inadmissible on the theory that an insanity defense might otherwise be seriously prejudiced because the jury could be misled into concluding that the accused was of sound mind on the date of the offense. ${ }^{32}$ But if a defendant himself introduces evidence that he was once adjudged incompetent to stand trial and that he was confined in a mental institution in that connection, he waives his right to exclude evidence that he has recovered his sanity and has been adjudged competent to be tried. ${ }^{33}$ In other words, a defendant who seeks to take advantage of a commitment order made to ascertain his competence opens the gate to otherwise inadmissible evidence which may totally undermine his insanity defense.

27. Wear v. United States, 218 F.2d 24 (D.C. Cir. 1954).

28. Committee on Mental Disorder as a Criminal Defense, Report to the Council on Law Enforceasent of the District of Columbia, in S. Rep. No. 1170, 84th Cong., 1st Sess. 5, 11 (1955).

29. Ibid.

30. D.C. Code Ann. \$ 24-301 (a) (Supp. VIII, 1960). By its terms, this statute supersedes in the District the provisions of 18 U.S.C. $\$ 4244$ (1958) which governs pre-trial competency motions in all other federal courts. D.C. CoDE ANN. $\$ 24301$ (h).

31. Report of the Comimttee on Mental Disorder as a Crininal Defense, $n$. cit. supra note 28.

32. 63 Stat. 686 (1949), 18 U.S.C. § 4244 (1958); see Lyles v. United States, 254 F.2d 725, 732 (D.C. Cir. 1957), cert. denied, 356 U.S. 961 (1958) (Prettyman and Burger, JJ.); Taylor v. United States, 222 F.2d 398 (D.C. Cir. 1955).

33. Lyles v. United States, 254 F.2d 725, 730-32 (D.C. Cir. 1957). 
On the whole, the statutory requirement that the accused produce "prima facie" evidence of incompetence as a prerequisite to a mental examination has been construed liberally. In March 1960, for example, roughly twenty per cent of all persons indicted in the District were undergoing pretrial mental examinations. $^{34}$ Such examinations are usually authorized on the basis of affidavits of defense counsel, typically court appointed, who affirm that the defendent's behavior during consultations and his personal history indicate the need for a psychiatric examination. ${ }^{35}$ A previous record of hospitalization in a mental institution, discharge from the armed forces on psychiatric grounds, or the nature of the offense itself may be sufficient to warrant the examination.

The prosecution itself has increasingly taken the initiative in requesting the court to order pretrial mental examinations, particularly in capital cases. ${ }^{36}$ The government's primary objective, however, is not to establish the accused's fitness to stand trial, but rather to gather evidence respecting the defendant's mental condition as of the date of the crime in order to rebut any claim of insanity at the time of the offense should such a defense be subsequently raised. A defendant is not required in the District to give notice to the prosecution in advance of trial that he will invoke the insanity defense. ${ }^{37}$ If a defendant conceals an intention to rely on an insanity plea for a long period after his indictment, the prosecution may find it difficult, or even impossible, to discharge its burden of proving that the defendant was of sound mind on the date of the offense. For that reason, the government seeks a mental examination shortly after the defendant's arrest on the theory that a reliable diagnosis of his mental condition is more likely - and is, therefore, of greater evidentiary value-than a psychiatric report based on a mental examination administered long after the crime. ${ }^{38}$

A pretrial mental examination in these circumstances may raise substantial constitutional questions. The presumption of innocence may well preclude a mental examination before indictment at the insistence of the prosecution, and effective protection of the privilege against self-incrimination may also require that no accused person be examined who is not represented by counsel.

34. The Washington Evening Star, March 4, 1960, p. B2, col. 1.

35. See Winn v. United States, 270 F.2d 326 (D.C. Cir. 1959); Calloway v. United States, 270 F.2d 334 (D.C. Cir. 1959).

36. See, e.g., Winn v. United States, 270 F.2d 326 (D.C. Cir. 1959).

37. See Judicial Conference of the District of Columbia Circuit, Proceedings, May 26, 1960, at 66; Gasch, supra note 10, at 6-7. Several states have enacted statutes which require the defendant to give notice of his intention to rely on the defense that he is not responsible. Model Penal Code $\$ 4.03$, comment (Tent. Draft No. 4, 1955). In the District of Columbia, the prosecution is typically alerted to the possibility that an insanity defense may be interposed by a defense motion for a mental examination to determine competence to stand trial.

38. "Presumably the less time that elapses between the act and the psychiatric examination, the more accurate will be the medical opinion." Blunt v. United States, 244 F.2d 355,364 n.23 (D.C. Cir. 1957). 
Further, the rights of the accused would seem to require that he be advised that he need not communicate with the government's psychiatrists, at least so long as he does not interpose an insanity plea. ${ }^{39}$ In any event, a psychiatric examination will be ordered more readily if the accused consents, and trial courts in the District tend to insist upon a stronger showing of necessity for the examination where the prosecution is the moving party.

\section{The Relationship Between Courts and Psychiatric Experts in Pre-Trial Proceedings}

Some of the most troublesome problems with respect to pretrial mental examinations relate to scope-(i) the scope of the mental examination which the courts direct psychiatrists to make as well as the breadth of the examination actually carried out, and (ii) the scope of the psychiatric report transmitted to the court. ${ }^{40}$ These problems are discussed below.

\section{The Scope of the Pretrial Mental Examination}

The controlling D.C. statute merely authorizes psychiatric tests, at the pretrial stage, to determine competence to stand trial. ${ }^{41}$ However, in order to obtain a psychiatric opinion with respect to the accused's mental condition at the time of the offense, a practice arose of requesting comprehensive mental examinations. Consistent with this practice, the prosecution in Winn v. United States ${ }^{42}$ filed a pretrial motion for a "complete and thorough mental examination" of a defendant who had hurled a three-day old child from a third story window. The trial court authorized a psychiatric examination limited to determining whether the defendant was capable of understanding the proceedings against him or assisting in his defense. In reversing the judgment, the Court of Appeals held that while the statute requires only an examination limited to competence to stand trial, it does not prohibit a more comprehensive examination. ${ }^{43}$ The court concluded that thorough psychiatric tests should be ordered "where it is obvious that the trial will revolve about the issue of the accused's mental state at the time of the crime ...." 44 Thus, the appellate court held in substance that a trial court has inherent power

39. See text at notes $68-79$ infra.

40. Some of the problems associated with a pretrial psychiatric examination considered in this section are discussed perceptively in an unpublished paper by J. William Doolittle, Jr., Scope of Pretrial Mental Examination of Accused Persons, prepared for a study group of the 1960 District of Columbia Judicial Conference.

41. D.C. Code ANN. \$ 24-301 (a) (Supp. VIII, 1960).

42. 270 F.2d 326 (D.C. Cir. 1959).

43. The Court assumed that a psychiatric examination to determine competence to stand trial is less intensive and thorough than a psychiatric examination designed to ascertain the accused's mental condition as of the date of the offense. Id. at 328 .

44. $270 \mathrm{~F} .2 \mathrm{~d}$ at 328 . A defendant who does not object to an order restricting the psychiatric examination to his competence to stand trial cannot challenge the scope of the examination on appeal. Willis v. United States, 285 F.2d 663 (D.C. Cir. 1960). 
to authorize a psychiatric examination, before trial, into the accused's mental state as of the date of the offense-the critical issue under the Durham test and other standards of responsibility. Hence, it is no longer necessary to request an examination respecting fitness to stand trial if the moving party's sole object is to obtain a professional opinion as to whether the accused was mentally diseased on the date of the crime.

The examining psychiatrists have been authorized to make whatever tests they deem necessary in order to advise the court of the defendant's mental condition. ${ }^{45}$ Brief jailhouse interviews may be adequate in the case of a severely disordered defendant who suffers from hallucinations and delusions. All of the medically recognized techniques for arriving at a diagnosis-physiological and neurological tests, electroencephalograph, and psychological tests-may be used when appropriate. Relatives of the accused, his employer, co-workers, and others may be interviewed by the psychiatrist, if necessary, to obtain background information essential to an informed opinion. ${ }^{46}$

\section{The Psychiatric Report}

Orders authorizing pretrial mental examinations direct the psychiatrists to report their opinion to the court. The statute contemplates that the district court will review the psychiatric report and that the court will independently determine whether the accused is competent to stand trial. Fitness to stand trial is not purely a psychiatric question but involves a "judgment based upon knowledge of criminal proceedings that is peculiarly within the competence of the trial judge."47

In many instances, the reports merely inform the court of the psychiatrists' ultimate conclusion. In a recent case, ${ }^{48}$ for example, the hospital's report to the court of a pretrial psychiatric examination read, in its entirety, as follows:

Jacob Calloway [the accused] was admitted to District of Columbia General Hospital July 18, 1958.

Psychiatric examination reveals this patient to be sane, competent and capable of participating in his own defense.

He may be returned to the Court at any time. ${ }^{49}$

45. See Williams v. United States, 250 F.2d 19, 23 (D.C. Cir. 1957) (dictum).

46. Ibid.; Calloway v. United States, 270 F.2d 334 (D.C. Cir. 1959).

47. Gunther v. United States, 215 F.2d 493, 497 (D.C. Cir. 1954).

48. Calloway v. United States, 270 F.2d 334, 335 (D.C. Cir. 1959).

49. Ibid. See also the hospital report to the court in Jones v. United States, 284 F.2d 245, 246 (D.C. Cir. 1960):

Mr. Jones' case has been studied intensively since the date of his admission to Saint Elizabeths Hospital and he has been examined by several qualified psychiatrists attached to the medical staff of Saint Elizabeths Hospital as to his mental condition. On April 6, 1959, Mr. Jones was examined and the case reviewed in detail at a medical staff conference. We conclude, as the result of our examinations and observation, that Arthur Jones is mentally competent to understand the proceedings against him and to properly assisț in his own dẹfense, 
On the basis of this report, Calloway was found competent by the District Court to be tried, and he was subsequently found guilty of assault with a dangerous weapon.

Reports as cursory as this one-particularly those containing the opinion that the defendant is incompetent-obviously do not constitute an adequate basis upon which a court can determine competence. A court cannot possibly make a "judgment" in a meaningful way if the psychiatric report contains only a naked conclusion without an underlying explanation. An opinion by an administrative agency which was drafted in such summary or conclusory form would be rejected out of hand.50

There is an even more basic vice in such conclusory reports-there is no basis for knowing the standard applied by the psychiatrist or the factors taken into account by him in reaching his conclusion that the defendant is or is not fit to stand trial. Competence to stand trial is not a psychiatric syndrome; it is a legal concept. The symptoms displayed by the patient must be related to the legal standard. For example, the psychiatrist may have followed the view that if the accused presently suffers from psychotic symptoms he is incompetent to stand trial. But there is no necessary correlation between psychosis and the relevant legal standard-capacity to understand the judicial proceedings and to assist in one's defense. A psychotic defendant conceivably could meet this standard $;^{51}$ on the other hand, a nonpsychotic defendant might well be incapable of assisting in his own defense by reason of his mental condition. A defendant could be so disoriented that he would not understand that he was in a courtroom on trial. But the mental disorder, even though severe, may be more subtle in its impact. The accused may suffer from a delusion that his counsel is an adversary to be resisted. He may suffer from a desire to inflict punishment upon himself, which could lead him to confess to acts which he had not committed. His mental condition may be such that he could not possibly take the witness stand in his own defense; on the other hand, his illness may impel him to insist upon taking the witness stand in defiance of his counsel's advice. It is true that counsel and the court can ascertain which, if any, of these symptoms the accused suffers from by calling the psychiatrist as a witness at a competency hearing. But there are many advantages in an informative report. In addition to compelling the examining psychiatrist to articulate his rationale, with the consequent likelihood of a more careful examination, a detailed report informs counsel in advance of the specific issues that will arise if the psychiatric opinion is challenged. Given a

50. The Administrative Procedure Act requires that an agency adjudication "include a statement of (1) findings and conclusions, as well as the reasons or basis therefor, upon all the material issues of fact, law, or discretion presented on the record." 60 Stat. 242 (1946), 5 U.S.C. $\$ 1007$ (1958).

51. "[S] omeone who is certifiably insane may often nevertheless be fit to plead to the indictment and follow the proceedings at the trial ...." Royal Comarission ON CAPITAL Punishament 1949-1953, Report, Caid. No. 8932, at 78. See also Model Penal Code $\&$ 4.04, comment (Tent. Draft No. 4, 1955). 
carefully prepared report, the prosecution may decide to acquiesce to a finding of incompetence, or the defense may determine to abandon any reliance on an insanity plea. Moreover, a comprehensive report may obviate the necessity for a hearing on the competency issue.

The psychiatric report should be specifically related to the legal test. In order to assist courts in arriving at an informed conclusion, a pretrial psychiatric report should contain minimally (a) a description of the nature of the psychiatric examination, e.g., the number and duration of psychiatric interviews or the type of psychological or neurological tests administered; (b) a statement of the clinical diagnosis; (c) a brief description of the symptoms; and (d) a statement of the specific, underlying reasons or findings to support the conclusion that the accused is or is not competent to be tried.52

Many of the foregoing problems also arise in connection with the related issue of determining whether a defendant, who has been adjudged incompetent and subsequently hospitalized, has recovered sufficiently to stand trial. The hospital authorities are required to advise the court when, in their opinion, the defendant "is restored to mental competency." 53 The psychiatric standards actually applied by the hospital authorities in reaching this conclusion, and the standards which should be applied by the district court in reviewing their opinion, have never been spelled out. In practice a large measure of discretion is vested in the hospital authorities in deciding when a defendant, who has been adjudged incompetent, will be brought to trial. A defendant who takes the initiative and seeks to have himself declared fit to stand trial operates under severe handicaps. His application is frequently opposed by the hospital psychiatrists on the grounds that he is not well enough to stand trial. Since the accused is usually indigent, he is generally unable to secure an outside psychiatric consultant in his behalf. ${ }^{54}$ Thus, the hearing on an application by a defendant to be adjudged competent to stand trial may be reduced to the testimony of a hospital staff psychiatrist, on the one hand, and that of the defendant himself, on the other. This situation is deplorable for at least two reasons. First, it is desirable that persons who are indicted should be brought to trial and afforded an opportunity to clear themselves. Second, many persons who are confined as incompetent harbor a deep sense of grievance that they are being detained though never found guilty of any wrongdoing. ${ }^{55}$ In short, there are strong policy reasons for giving parties who wish to establish their competence the fullest possible assistance.

52. See Model Penal Code $\$ 405$ (Tent. Draft No. 4, 1955).

53. D.C. CoDe Ann. § 24-301(b) (Supp. VIII, 1960).

54. The D.C. Court of Appeals ruled recently that a person found not guilty by reason of insanity and seeking release from hospital confinement could demand the expert testimony of psychiatrists attached to the District's Commission on Mental Health. Curry v. Overholser, No. 15,848, D.C. Cir., Nov. 23, 1960, at 6-7. In principle, the same assistance should be available to persons adjudicated incompetent who are seeking to establish their fitness to stand trial.

55. See Model Penat Code $\$ 4.04$, comment (Tent. Draft No. 4, 1955). 


\section{Problems Arising from Delays in Competency Proceedings}

A number of questions have arisen in the District as a result of delays connected with pretrial competency proceedings. The delay may be due simply to the time required to complete psychiatric tests. In the typical case when a motion for a mental examination is granted, a defendant is hospitalized about 90 days before a psychiatric report is submitted to the court. ${ }^{56}$ A shortage of psychiatric personnel and inadequate hospital facilities account for most of this delay. ${ }^{57}$ Delay of an altogether different character will ensue if the defendant is adjudged unfit to stand trial. He will then be ordered hospitalized until he is found competent to be tried. It is not uncommon for a defendant, who has been found incompetent, to be hospitalized for two or three years before being bought to trial.

A defendant's right under the sixth amendment to a speedy trial may be seriously compromised by these delays. Witnesses may disappear; memories will fade. It is clear, of course, that delay in the trial date solely because of the defendant's mental condition will not, without more, justify dismissing the indictment. ${ }^{58}$ But if the period of hospital confinement is of long duration, the prosecution may be compelled to prove that no prejudice resulted to the defendant from any delay, apart from that attributable to the inevitable postponement necessitated by treatment. ${ }^{59}$

The delays and long periods of confinement associated with competency proceedings may inhibit motions by the defense for a pretrial mental competency examination in some cases. If the felony with which the defendant is charged bears only a short prison term upon conviction, an accused who pleads guilty conceivably could be released before he would be brought to trial were he found incompetent to stand trial. ${ }^{60}$ In addition, the likelihood that bail will be denied to a party awaiting a pretrial mental examination may deter defense counsel from seeking a psychiatric report.

The mental condition of the defendant may be such as to require even that the trial be permanently deferred. While a defendant found incompetent and hospitalized must be brought to trial promptly after he is "restored to mental

56. Judicial Conference of the District of Columbia Circuit, Proceedings, May 26, 1960, at 61, 63. In March 1960, the D.C. District Court denied an application for release by a defendant who had been confined 105 days waiting a psychiatric examination. The Washington Post \& Times Herald, March 4, 1960, p. 3, col. 2.

57. "[O]ur problem of delay seems to resolve itself into a problem of personnel. . . . [T] he delays . . . in part are the result of under-staffed hospital facilities." Proceedings, supra note 56 , at $62-63$.

58. See Williams v. United States, 250 F.2d 19 (D.C. Cir. 1957).

59. Ibid.

60. "For all that appears, appellant and his former counsel concluded that a jail sentence on two of the ten counts would be preferable to a mental examination under the Miller Act or under Section 24301 of the District of Columbia Code, with the possibility thereafter of an extended period of confinement in St. Elizabeths." Carter v. United States, 283 F.2d 200, 203 (D.C. Cir. 1960), 
competency " it is possible that the accused may never recover sufficiently to stand trial. May such an individual be detained indefinitely? This issue was raised dramatically in the proceedings involving Ezra Pound, the noted poet, who was indicted in 1945 on charges of treason and then found unfit to stand trial. ${ }^{01}$ Pound was held in St. Elizabeths Hospital, a federally operated mental institution in the District, for fourteen years. The indictment against him was dismissed, and he was finally released in 1958 after the hospital superintendent advised the District Court that Pound suffered from a permanent and incurable paranoid state, that further treatment was useless, that there was no likelihood that he would ever be sufficiently competent to stand trial, and that he would not be dangerous if he were released. ${ }^{62}$

The Pound case supports the view that an accused person who in all probability will never be fit to stand trial, may not be permanently confined pursuant to a pretrial order in a criminal case, provided that he will not be dangerous to himself or others if discharged. The justification for hospitalizing an incompetent person who has been indicted is that he may respond to treatment sufficiently to stand trial; however, if recovery is improbable, continued detention is not warranted. Indeed, it can be persuasively argued that due process requires that a defendant should be released even though he may be dangerous if it appears that he will never recover sufficiently to stand trial. ${ }^{63}$ The power to confine an individual for a "reasonable period" to determine whether he is fit to stand trial may be defended as a necessity if an informed conclusion is to be reached as to competence; but if a trial can never occur there is no justification for continued detention. Indefinite confinement of a person who has never been tried or found guilty of any offense cannot be supported by a procedural device of such limited scope.

The community is not denied all protection by this conclusion. Coincident with the defendant's release, civil commitment proceedings may be initiated if he is mentally ill and dangerous. ${ }^{64}$ But a civil commitment proceeding, in the District of Columbia as elsewhere, is accompanied by numerous procedural safeguards, including the right to a jury trial..$^{65}$

The issue left open by the Pound proceeding is how long a defendant may be detained before he must be released on the grounds that he will in all likelihood never be competent to stand trial. In some instances, this conclusion can be reached by the hospital authorities within a few months; in other cases,

61. United States v. Pound, Crim. No. 76028, D.D.C., Nov. 26, 1945.

62. Affidavit of Dr. Winfred Overholser, April 14, 1958, ibid.

63. In a concurring opinion in Ragsdale v. Overholser, 281 F.2d 943 (D.C. Cir. 1960), Judge Fahy maintains that even in the case of an individual tried and acquitted by reason of insanity, "the validity of continued confinement [in a hospital] . . may require that, unless within a reasonable time he progresses toward becoming not dangerous to self or community, the person committed can be held only by a separate civil adjudication of unsoundness of mind ...." Id. at 950 .

64. See Overholser v. Williams, 252 F.2d 629 (D.C. Cir. 1958).

65. See Williams v. Overholser, 259 F.2d 175 (D.C. Cir. 1958). 
a long period of observation and treatment will be necessary before a reasoned opinion can be offered as to the prospects for recovery. In any event, the Pound case exposed a deficiency in the District's statutory procedure. It would appear desirable to provide that at specified intervals the hospital authorities must submit a report to the court containing their most recent diagnosis, a description of the course of the treatment, and their provisional prognosis. ${ }^{00}$ Defendants less well known than Ezra Pound may otherwise languish for years in a mental institution, although innocent of any wrongdoing.

\section{Questions Arising from the Refusal of an Accused Person to be Interviewed by the Psychiatric Consultants}

Some defendants, who have been ordered hospitalized to determine their competence to stand trial, have refused, upon advice of counsel, to participate in a psychiatric interview. ${ }^{67}$ It has been argued in behalf of such persons that the privilege against self-incrimination justifies the refusal to communicate with the psychiatric consultants. ${ }^{68}$

It is possible in some cases for a psychiatrist to make a provisional diagnosis without actually interviewing the patient. $\mathrm{He}$ can do so by observing the defendant's behavior over a long period, or upon the basis of information supplied by intimate associates of the patient or by other persons who have had contact with him. The psychiatric interview is, however, the basic diagnostic tool, ${ }^{69}$ and a patient's refusal to speak to the psychiatrist may seriously impede a prompt and reliable diagnosis. ${ }^{70}$

66. It has been recommended that the hospital submit a report to the court with respect to the accused's mental condition at least every six months. Proceedings, supra note 56 , at 65 .

67. See The Washington Post \& Times Herald, April 29, 1960, p. D1, col. 2. See also Halleck, The Insanity Defense in the District of Columbia-A Legal Lorelei, 49 GEo. L.J. 294, 302-03 (1960).

68. See The Washington Post \&t Times Herald, July 21, 1960, p. A3, col. 6.

69. See Sullivan, The Psychiatric Interview (1954). Sullivan defines a psychiatric interview as a "situation of primarily vocal communication in a two-groutp, more or less volntutarily integrated, on a progressively unfolding expert-client basis for the purpose of elucidating characteristic patterns of living of the subject person, the patient or client, which patterns he experiences as particularly troublesome or especially valuable, and in the revealing of which he expects to derive benefit." Id. at 4. (Emphasis in original.)

70. A proper examination calls first of all for a physical examination and if possible an electroencephalogram to determine from what are colloquially known as "brain waves" whether or not there is a tendency toward epilepsy or some other gross abnormality of the brain. The presence or absence of gross neurological changes should be tested. A reasonably full history of the individual is essential, together with various psychological tests; the history should be obtained from the subject himself and from outside sources. No one is an entirely dependable source of information about his own conduct, particularly in criminal cases, where self-serving and self-exculpatory declarations are likely to be met. The psychiatric interview should include not only the history but the ascertaining of the presence or absence of delusions and hallucinations, evaluation of the judgment of the subject, his recognition of his relations with those about him or what we term orientation, his 
A defendant's unwillingness to participate in a psychiatric interview may in itself be a symptom of severe mental disorder. But the accused's refusal may be a voluntary act in accordance with the advice of counsel. ${ }^{71}$ The legal ramifications of this latter type of refusal varies with the procedural setting. A defendant who seeks a pretrial psychiatric examination to determine competence cannot, of course, consistently refuse to be examined. It would not, therefore, appear unjust for a trial court to hold that such a defendant is presumptively competent to be tried.

The question becomes considerably more complex, however, at the trial stage. A noncooperative defendant may interpose the substantive defense that he suffered from a mental disease or defect at the time of the offense. The District of Columbia follows the federal rule that once sanity is in issue, the prosecution is required to prove beyond a reasonable doubt that the accused was of sound mind at the time of the offense. ${ }^{72}$ In these cases the government may be compelled to produce expert testimony that the accused is of sound mind, particularly if the defendant offers experts in his behalf. There is, thus, considerable force to the contention of prosecuting attorneys that it is intolerable to impose the burden of persuasion upon the government while allowing the accused to foreclose access to essential data which can be obtained only from the defendant himself and which the prosecution requires in order to discharge its burden. ${ }^{73}$

This issue has not yet been authoritatively resolved in the District. But there may be several possible solutions.

First. It has been suggested that the self-incrimination objection is unsound. One commentator has observed:

The privilege protects the accused from supplying any testimonial link in the chain of evidence to establish the conclusion that he committed the crime in question; it has no application to an inquiry as to his mental responsibility at the time the act was committed; for even though an accused's guilt depends upon his mental condition at the time of the commission of the act, a psychiatric examination has no bearing upon the question of whether he actually committed it. ${ }^{4}$

This view of the scope of the fifth amendment is reflected in the doctor-patient privilege which has developed in the District of Columbia. A psychiatrist can-

memory, his thought processes and his emotional reactions, such as undue elation or depression or indifference. Overholser, Criminal Responsibility-A Psychiatrist's Viewpoint (unpublished manuscript).

71. See The Washington Post \& Times Herald, April 29, 1960, p. D1, col. 2.

72. See note 160 infra and accompanying text.

73. There are, of course, countless instances where a defendant has knowledge of infornation helpful to the prosecution which he cannot be required to divulge. The situation presented here, however, appears to be unique in that (i) the issue involved is raised by the defendant; (ii) if the issue is raised, the government bears the ultimate burden of proof; and (iii) information which is essential in discharging the burden can be obtained in most cases only from the person of the defendant.

74. Inbau, Self Incrimination 55 (1950). 
not divulge, over the defendant's objection, any information communicated to him in his professional capacity which could be used as evidence that the accused commited the act in question. ${ }^{75}$ However, the doctor-patient privilege in the District has been made inapplicable "to evidence relating to the mental competency or sanity of the accused in criminal trials where the accused raises the defense of insanity."76 In brief, statements by the accused to a psychiatrist bearing on commission of the offense are privileged, but statements pertinent to the accused's mental condition are admissible. Thus, for example, a defendant cannot prevent disclosure by a psychiatrist on the witness stand of an admission by the accused that he was feigning insanity, but the defendant can block any disclosure of a confession of guilt made to the psychiatrist.

If the privilege against self incrimination is not a valid basis for refusal by an accused person to speak to a psychiatrist, there would appear to be no valid reason why the prosecution could not offer evidence in rebuttal to a claim of insanity that the defendant had declined to be interviewed. ${ }^{77}$ The prosecution could also request an instruction to the effect that although the accused was not obligated as a matter of law to submit to a psychiatric examination, he had refused to do so, and his unwillingness could be weighed by the jury in appraising the defendant's claim that he was mentally diseased.

This argument, however, may proceed from a faulty premise. It assumes that the defendant's mental condition at the time of the offense is not covered by the privilege. But mens rea is, of course, as essential an element in proving an offense as evidence bearing upon commission of the act itself. It is difficult to justify a view of a constitutional privilege which is so technical and restrictive.

Second. A more radical solution would be to exclude evidence of insanity tendered by an accused who voluntarily refuses to be examined. Even if the right to plead insanity is constitutionally protected, it does not follow that reasonable conditions cannot be annexed to exercise of the right. Hence, willingness to be examined could be made a condition of raising the defense. ${ }^{78}$

75. Edmonds v. United States, 260 F.2d 474 (D.C. Cir. 1958).

76. D.C. Code ANn. $\$ 14-308$ (Supp. VIII, 1960). See Report of the CoMmittee on Mental Disorder as a Criminal Defense, op. cit. supra note 27, at 14-16.

77. If refusal to communicate with a psychiatrist is protected by the self incrimination provisions of the fifth amendment, neither court nor counsel can call the attention of the jury to the unwillingness of the accused to be examined. See Adamson v. California, 332 U.S. 46, 50 (1947).

78. Cf. People v. Esposito, 287 N.Y. 389, 397-98, 39 N.E.2d 925, 928 (1942) (upholding the admissibility of statements made to psychiatrists by accused persons while under the influence of drugs):

It must be remembered that the orders for the [mental] examination and observation were based upon the defendants' claim that they should escape punishment by reason of their mental condition at the time of . . . arraignment and trial. Under those circumstances defendants may not both advance their claims and then seek to make the rules for the determination of those claims. Since they desired to present their claims that they were not legally responsible for their acts because of mental defect they were subject to the use of methods set up objectively by the medical pro- 
However, this approach may be foreclosed by a recent pronouncement of the Court of Appeals that there is "almost a positive duty on the part of the trial judge not to impose a criminal sanction on a mentally ill person."79

A limitation on both of these approaches to the problem of the noncooperative defendant is that they presuppose an accused who is capable of making a rational choice between submitting to an examination or foregoing the insanity defense. It may on occasion be difficult to distinguish between a disordered defendant whose refusal to communicate is a symptom of his illness, and an accused-who may or may not be mentally ill-who refuses to be interviewed on advice of counsel. Yet some adjustment is needed between the interests of the noncooperative defendant who pleads insanity and the prosecution which is shouldered with the burden of proving the accused sane, but which is denied access to those techniques generally accepted as prerequisites to reliable diagnoses. ${ }^{80}$ Objections by the defense to a psychiatric interview might diminish if there were a requirement that mental examinations be conducted by an impartial, independent board of medical experts, ${ }^{81}$ closely supervised by the court. This might provide an attractive alternative to the current system whereby examinations of this kind are administered by doctor-employees of the government.

\section{Trial Problems Under the Durham Rule}

\section{The Post-Durham Status of the M'Naghten, Irresistible Impulse, and Diminished Responsibility Tests}

At the trial, the substantive rule of responsibility determines the character of the evidence as to mental disorder and the instructions which will be given to the jury. When Durham was decided, the substantive tests of criminal responsibility in the District were the M'Naghten right and wrong rule ${ }^{82}$ and the irresistible impulse test. ${ }^{83}$

fession for the proper determination of such claims. Courts, under the circumstances presented here, may not control the methods which have been determined by the medical profession to be proper means for discovering or treating mental diseases.

79. Overholser v. Lynch, No. 15859 , D.C. Cir., Jan. 26, 1961, at 8. See text at notes 174-78 infra.

80. In addition to the solutions discussed in the text, it has also been proposed that the rules as to the burden of proof should be changed in the case of a noncooperative defendant; the accused would be required to prove that he was of unsound mind. Accord, Leland v. Oregon, 343 U.S. 790 (1952).

81. A plan to use impartial medical experts in personal injury actions is now under consideration in the District of Columbia. Washington Post \& Times Herald, Dec. 1, 1959, p. B13, col. 4.

82. (Emphasis in original.) M'Naghten's Case, 10 Cl. \& Fin. 200, 210 (H.L. 1843) : [T] he jurors ought to be told in all cases that every man is to be presumed to be sane, and to possess a sufficient degree of reason to be responsible for his crimes, until the contrary be proved to their satisfaction; and that to establish a defence on 
The Durham decision left the future status of these two pre-existing tests in doubt. ${ }^{84}$ In 1956, about two years after Durham, the Court of Appeals made clear that it had not intended "to bar all use of the older tests." court subsequently explained: "While capacity to distinguish right from wrong is no longer the earmark of legal sanity, the lack of that capacity is one of the earmarks of legal insanity." " Accordingly, testimony that the accused cannot differentiate right from wrong or that he acted because of an uncontrollable impulse is presently admissible in the District. ${ }^{87}$ And if the testimony so warrants, the jury must be instructed to consider these symptoms, as well as all others, in deciding the ultimate issue of responsibility-whether the criminal act was the product of mental disease or defect. ${ }^{88}$

Like the M'Naghten and irresistible impulse standards, the Durham rule does not recognize the gradations between sanity and insanity which are affirmed by nearly all mental health specialists. ${ }^{89}$ An accused is either sane, and therefore completely responsible, or he is of unsound mind, and thus

the ground of insanity, it must be clearly proved that, at the time of the committing of the act, the party accused was labouring under such a defect of reason, from disease of the mind, as not to know the nature and quality of the act he was doing; or, if he did know it, that he did not know he was doing what was wrong.

The first reported case in the District in which the right and wrong test was applied was the trial of Charles Guiteau, President Garfield's assassin, in 1881. Guiteau's Case, 10 Fed. 161 (D.D.C. 1882) ; Guiteau's Case, 12 D.C. (1 Mackey) 498 (D.C. Sup. Ct. 1882). For a recent review of the Guiteau case which indicates that there are substantial grounds for believing that Guiteau suffered from paranoia, see Donovan, Amals of Crime: The Impression, The New Yorker, April 24, 1954, p. 91.

83. A defendant is immune from punishment under this test if it is proved that he was "impelled to do the act by an irresistible impulse," that is, if "his reasoning powers were so far dethroned by his diseased mental condition as to deprive him of the will power to resist the insane impulse to perpetrate the deed, though knowing it to be wrong." Smith v. United States, 36 F.2d 548, 549 (D.C. Cir. 1929).

84. The Durham decision, by its terms, applied only prospectively so that verdicts rendered before July 1,1954 , under the pre-existing tests were not disturbed on appeal. Stogner v. United States, 229 F.2d 513 (D.C. Cir. 1955) ; Jordan v. United States, 217 F.2d 670 (D.C. Cir. 1954).

Some trial judges in the District were of the view that Durham had abolished the M'Naghten and irresistible impulse tests, see Wright v. United States, 250 F.2d 4, 12 (D.C. Cir. 1957), while other trial judges allowed counsel to examine witnesses in terms of the older tests and charged juries in terms of both the Durham rule and the pre-existing tests.

85. Douglas v. United States, 239 F.2d 52, 58 (D.C. Cir. 1956).

86. Wright v. United States, 250 F.2d 4, 12 (D.C. Cir. 1957). (Emphasis in original.)

87. Stewart v. United States, 247 F.2d 42,44 (D.C. Cir. 1957).

88. Misenheimer v. United States, 271 F.2d 486 (D.C. Cir. 1959).

89. [T]o the psychiatrist mental cases are a series of imperceptible gradations from the mild psychopath to the extreme psychotic, whereas criminal law allows for no gradations.

Holloway v. United States, 148 F.2d 665, 667 (D.C. Cir. 1945). See OverHolser, The Psychiatrist and the LaW 44-46 (1953); Guttmacher \& Weiroffen, Psychiatry AND THE LAW 428-33 (1952). 
totally exempt from punishment. In a pre-Durham case decided in 1945, Fisher v. United States, ${ }^{20}$ the Court of Appeals was urged to recognize that there are persons who are not insane but whose mental powers are so deficient that it would be unjust to hold them fully responsible. Fisher was charged with first degree murder. The District of Columbia statute defining this offense is unique in that it expressly requires that the homicide be committed by a person of "sound memory and discretion." 91 There was evidence that Fisher was a person of low grade mentality, and psychiatric testimony was presented to the effect that Fisher was a "psychopathic personality of the predominantly aggressive type." 02 The defense maintained that Fisher's mental condition was such that he lacked the "sound ... discretion" required for a conviction of first degree murder, and argued that the jury should be permitted to find Fisher guilty of a lesser offense, specifically second degree murder. In substance, the defense urged adoption of a test of diminished responsibility in capital cases.

The trial court refused to grant the requested instruction. Fisher was found guilty and sentenced to death. In sustaining the trial court, the Court of Appeals acknowledged that, "Modern psychiatry has given us much scientific information which disturbs the former certainty of our judgments of individual responsibility and moral guilt." 93 The court was unwilling, however, to sanction the diminished responsibility notion: "In the determination of guilt, age old conceptions of individual moral responsibility cannot be abandoned without creating a laxity of enforcement that undermines the whole administration of criminal law." The Supreme Court refused to disturb the judgment on the grounds that acceptance of the partial responsibility doctrine "would involve a fundamental change in the common law theory of responsibility," a change which the court felt should properly be made by Congress or by the District of Columbia courts. ${ }^{95}$

In 1954, while the Durham case was sub judice, the D.C. Court of Appeals was urged in a capital case involving a borderline mental defective to reconsider its ruling in Fisher and to approve the partial responsibility test.96 The court declined to do so, saying that it wished an adequate opportunity to apraise the operation of the then newly adopted Durham test. ${ }^{97}$ In 1960 , after

90. 149 F.2d 28 (D.C. Cir. 1945), aff'd, 328 U.S. 463 (1946).

91. D.C. CODE ANn. § 22-2401 (1951).

92. 149 F.2d at 29. There was no testimony that Fisher was not aware of the difference between right and wrong, the then applicable test of responsibility, and on appeal it was conceded that he was "sane in the usual legal sense." 328 U.S. at 466.

93. 149 F.2d at 29 .

94. Ibid.

95. 328 U.S. at 476. Justices Frankfurter, Murphy, and Rutledge dissented.

96. Brief for Abram Chayes as Amicus Curiae, Stewart v. United States, 214 F.2d 879 (D.C. Cir. 1954).

97. 214 F.2d at 883 . The conviction was reversed, however, because of a misleading instruction by the trial judge to the effect that psychopaths were criminally responsible. 
six years of experience under Durham, the court flatly rejected the diminished responsibility doctrine. ${ }^{98}$ The court concluded that:

The problem of classifying, assessing and analyzing the results of the application of modern psychiatry to administration of the criminal law as it relates to gradations of punishment according to the relative intelligence of the defendant is beyond the competence of the judiciary. . . . The basic framework for sentences of punishment must be established by the legislative branch. ... . That must be done by long range studies by competent public and quasi-public entities and by legislative committees with trained staffs aided by objective technical and scientific witnesses who can deal with all aspects of the problem .... ${ }^{99}$

The court's rationale is curiously inconsistent with its willingness to exercise its rule-making power as evidenced by its adoption of the Durham rule itself. Its rejection of the diminished responsibility doctrine may be explicable on different grounds which were not articulated. The Durham and diminished responsibility tests each have a common ethical core: It is wrong and futile to punish the blameless-those who are not and will not be influenced by punitive sanctions. ${ }^{100}$ But the insanity test evolved in the District has another justifcation-that in certain cases hospitalization and treatment may afford greater protection to the community in the long run. ${ }^{101}$ The diminished responsibility test does not further this latter objective, since the plea is invoked only to mitigate punishment. The defendant, if found guilty, is imprisoned or fined, but he is not hospitalized and treated.

The diminished responsibility rule can serve an important office in jurisdictions which still adhere closely to the M'Naghten rule and which permit capital punishment; it is a useful doctrinal device for avoiding the death penalty where there is evidence of substantial impairment of mental capacity. In the District of Columbia, on the other hand, the Durham test is sufficiently broad to take account of such cases, and bills have been introduced in Congress to abolish the mandatory death sentence in capital cases in the District. ${ }^{102}$ These circumstances have dulled the drive for adoption there of the diminished responsibility doctrine.

98. Stewart v. United States, 275 F.2d 617, $623-24$ (D.C. Cir.), cert. granted, 363 U.S. 818 (1960).

99. 275 F.2d at 624 .

100. "Our collective conscience does not allow punishment where it cannot impose blame." Holloway v. United States, 148 F.2d 665, 666-67 (D.C. Cir. 1945).

101. Two policies underly the distinction in treatment between the responsible and the nonresponsible: (1) It is both wrong and foolish to punish where there is no blame and where punishment cannot correct. (2) The community's security may be better protected by hospitalization under D.C. Code, $\S 24-301$ than by imprisonment.

Williams v. United States, 250 F.2d 19, 25-26 (D.C. Cir. 1957). See also Douglas v. United States, 239 F.2d 52, 60 n.12 (D.C. Cir. 1956).

102. S. 2083, 86th Cong., 1st Sess. (1959); see Blocker v. United States, 274 F.2d 572, 574 n.1 (D.C. Cir. 1959) (dissenting opinion). 
The Status Under the Durham Rule of Psychopaths, Intellectually Deficient Individuals, and Persons Suffering from Psychoneurotic Disorders

The Durham test was deliberately designed to encompass every type of mental illness. ${ }^{103}$ Controversy has still arisen with respect to the status under the Durham rule of (i) psychopaths, (ii) individuals who have a defect of intelligence such that they would be classified as mentally deficient in varying degrees, and (iii) persons who suffer from mental disorders which are not clinically diagnosed as psychotic or as psychopathic, but which are usually deemed to be psychoneurotic disorders.

(i) Psychopaths (or "sociopaths with an anti-social reaction," the nomenclature preferred by the American Psychiatric Association) have been defined as

chronically antisocial individuals who are always in trouble, profiting neither from experience nor punishment, and maintaining no real loyalties to any person, group or code. They are frequently callous and hedonistic, showing marked immaturity with lack of sense of responsibility, lack of judgment, and an ability to rationalize their behavior so that it appears warranted, reasonable and justified.104

In most jurisdictions, psychopaths are held criminally responsible. ${ }^{105}$ This principle is justified in part on the theory that psychopaths do not differ qualitatively from normal persons. ${ }^{106}$ Moreover, many psychiatrists believe that psychopaths are not amenable to treatment, or that only certain types of psychopaths can be aided by intensive therapy, so that commitment to already overcrowded mental institutions would be pointless. While some psychiatrists regard psychopaths as mentally diseased, others disagree with this classification. ${ }^{107}$ On the other hand, there is widespread consensus among psychia-

103. See Briscoe v. United States, 248 F.2d 640, 641 n.2 (D.C. Cir. 1957) (Bazelon, J.).

104. American Psychiatric Association, Diagnostic and Statrstrcat ManualMental Disorders 38 (1952). The Mental Health Act, adopted in England in 1959, defines psychopathy as "a persistent disorder or disability of mind ... which results in abnormally aggressive or seriously irresponsible conduct on the part of the patient and requires or is susceptible to treatment." $7 \& 8$ Eliz. 2, c. 72.

The term "psychopathic personality" has "been used for many years as a convenient psychiatric waste-basket for cases otherwise difficult to classify." REPORT, N.J. CoMrM'N on Habitual Sex Offender 39 (1950). See also Kozol, The Psychopath Before the Law, 260 New Eng. J. of MEd. 637 (1959) ; Inglis, The Psychopath, Encounter, Sept. 1960, p. 3.

105. See Weinofen, Miental Disorder as a Criminal Defense 26, 123 (1954).

106. See Report of the Royal Conmission, op. cit. supra note 51, at 139:

For the present we must accept the view that there is no qualitative distinction, but only a quantitative one, between the normal average individual and the psychopath, and the law must therefore continue to regard the psychopath as criminally responsible.

In England, as a result of the Homicide Act of 1957, a psychopath may in certain circumstances invoke the diminished responsibility test in defense to a charge of murder. Rex v. Byrne, [1960] 2 Q.B. 396.

107. [S] ome psychiatrists will consider psychopathy a mental disorder, and many among the more analytically oriented even a mental disease, while others, chiefly 
trists that psychopaths are significantly less capable of self-control than normal persons;108 they may be "subject to aggressive or perverted urges as much beyond their control as a tidal wave."109

In form, the law in the District applicable to psychopaths differs from the generally accepted view that evidence of psychopathy will not justify an acquittal on grounds of insanity. Under the Durham test, it is for the jury to decide whether an individual with the personality traits of a psychopath suffers from a mental disease such that he should not be held criminally responsible. 110 Evidence that the defendant has been diagnosed as a psychopath justifies submission of the insanity defense to the jury, and it has been held to be reversible error for a trial judge to charge a jury that a psychopath "is not within the definition of insanity as defined by law."'111

In practice, however, psychopaths are almost invariably held accountable in the District. Psychopaths are commonly counseled not even to raise the insanity defense because of the D.C. statute requiring automatic, compulsory hospitalization of all persons found not guilty by reason of insanity and decisions strictly construing the release provisions of this act.112 The Court of Appeals has ruled in substance that a defendant acquitted on insanity grounds may be detained until the hospital superintendent and the district court are satisfied that he does not suffer from an "abnormal mental condition" which makes him dangerous. ${ }^{113}$ Since psychopaths are deemed to be "mentally abnormal" even by many psychiatrists who do not classify them as mentally "diseased," and since psychopaths frequently have long records of delinquency, there is substantial liklihood that they will be hospitalized for an indefinite period if found not guilty because of insanity. In brief, although the Durham rule extends to psychopaths, few psychopaths actually invoke the defense, and the practical situation in the District with respect to psychopaths remains substantially as it was prior to July 1,1954 . There is one significant qualification:

those of the old school, will slough these off as merely instances of a "behavior disorder."

Model Penal Code $\$ 4.01$, app. C (Tent. Draft No, 4, 1955).

Those psychiatrists who would regard such persons as the victims of disease proceed upon the theory that capacity for law-abiding living in society if a constituent of mental health, with the conclusion that its absence is disease; or else on the hypothesis that psychical disorder underlies all maladjustments of this kind although the present state of knowledge may not serve to explicate the nature of the psychical disorder except in terms of its results.

New York Governor's Conference on the Defense of Insanity, Interim Report of the Study Committee, N.Y. May 29, 1958, p. 4 (mimeographed draft). .

108. See Report of the Royal Cominission, op. cit. supra note 51, at 137.

109. Cross, The Plea of Diminished Responsibility, The Listener, Jan. 5, 1961, p. 10.

110. Stewart v. United States, 214 F.2d 879 (D.C. Cir. 1954) ; Taylor v. United States, 222 F.2d 398, 404 (D.C. Cir. 1955).

111. Ibid.

112. See text at notes 197-204 infra.

113. See Overholser v. Leach, 257 F.2d 667 (D.C. Cir. 1958). 
Under Durhann, the way is open for seriously disordered psychopaths to plead insanity, so that it is at least possible in the District of Columbia for a psychopath to be held exempt from criminal responsibility.

(ii) An intelligence defect may range from mild (an impairment connected with an I.Q. rating of 70 to 85 ), to modest (a functional impairment requiring special vocational training and associated with an I.Q. rating of about 50-70) to severe (an I.Q. below 50, requiring custodial care). ${ }^{114}$ It has been argued that individuals who suffer from moderate to severe defects are incapable of criminal intent, ${ }^{115}$ and that such persons should consequently be held exempt from criminal responsibility. There is no doubt, for example, that "in the feebleminded, judgment, moral sense, and appreciation of right and wrong are defective, and the power of self-control is substantially less than that of a normal person. ${ }^{116}$

Evidence of low scores on intelligence tests was at first proferred in the District in support of the diminished responsibility doctrine. ${ }^{117}$ After the Court of Appeals refused to sanction that test, such evidence was tendered as proof of the fact that the defendant suffered from a mental "defect" within the meaning of the Durham rule. In other words, it was urged that evidence of an extremely low I.Q. score could justify total exemption from criminal responsibility. ${ }^{118}$ The Court of Appeals has held, however, that such evidence is not sufficient to warrant a Durham instruction to the jury. ${ }^{119}$ The court was heavily influenced by the view that there is no "absolute accuracy and reliability" for intelligence tests, and that the results in such tests can vary materially depending upon the education and background of the person being tested.120 The court thus regards I.Q. tests, which have the facade of arithmetical certainty, as less reliable in helping to determine responsibility, than a psychiatric diagnosis.

(iii) The Durham rule was invoked by a pyromaniac who set fires to gratify sexual urges, ${ }^{121}$ and it would be applicable to the compulsive thief. The Durham rule has rarely been asserted, however, by persons suffering from psycho-

114. American Psychiatric Association, Diagnostic and Statistical ManualMental Disorders 23-24 (1952).

Persons with an I.Q. rating of 0-25 are classified as idiots, 25 to 50 as imbeciles, 50 to 70 as morons, and 70 to 90 as borderline. Noyes \& Kolb, Modern Clinical Psychiatry 330 (5th ed. 1958).

115. See Stewart v. United States, 275 F.2d 617, 623 (D.C. Cir.), cert. granted, 363 U.S. 818 (1960).

116. See Rerort of the Royal Comarssion, op. cit. supra note 51, at 121.

117. See Fisher v. United States, 328 U.S. 463, 467 (1946) ; Stewart v. United States, 214 F.2d 879 (D.C. Cir. 1954).

118. See Moore v. United States, 277 F.2d 684 (D.C. Cir. 1960).

119. Ibid.

120. See Stewart v. United States, 275 F.2d 617, 624 n.10 (D.C. Cir.), cert. granted, 363 U.S. 818 (1960).

121. See Briscoe v. United States, 248 F.2d 640 (D.C. Cir. 1957) ; Briscoe v. United States, 251 F.2d 386 (D.C. Cir. 1958). 
neurotic disorders, although evidence of such a condition might be sufficient in an appropriate case to warrant submitting to the jury the question of the defendant's responsibility. The rarity of the Durham plea by persons with psychoneurotic disorders may be attributable, in part, to the widely held belief that only psychotic disorders constitute a basis for exemption from criminal responsibility. ${ }^{122}$ And since many psychiatrists do not classify persons with neurotic disorders as mentally "diseased," defense counsel may encounter difficulty in securing medical evidence to support an insanity defense in such cases.

In sum, the Durham test has been invoked primarily by psychotics, occasionally in behalf of psychopaths, and rarely in the case of persons suffering from other types of mental disorders.

\section{The Psychiatric Expert Under the Durham Test}

The Durham rule is designed to overcome barriers to communication between psychiatric experts and the courts erected under the M'Naghten and irresistible impulse tests. ${ }^{123}$ The test is designed to afford the jury a maximum opportunity to hear evidence which may shed light on the defendant's conduct. It is designed to encourage a psychiatrist-a trained investigator in motivation and behavior - to communicate to the jury, in his own terms, his expert opinion respecting the defendant's mental condition at the time of the offense. ${ }^{124}$ In brief, a chief objective of Durham and related decisions has been improvement in the "quality and candor" of psychiatric testimony. ${ }^{12 \pi}$

In delineating the proper function of expert testimony in a criminal case involving insanity, the Court of Appeals has emphasized that "Unexplained medical labels-schizophrenia, paranoia, psychosis, neurosis, psychopathyare not enough. . . . The chief value of an expert's testimony in this field, as in all other fields, rests upon the material from which his opinion is fashioned and the reasoning by which he progresses from his material to his conclusion; in the explanation of the disease and its dynamics, that is, how it occurred, developed, and affected the mental and emotional processes of the defendant; it does not lie in his mere expression of conclusion." ${ }^{126}$

A definitive judgment concerning the extent to which the Durham formula has in fact improved the quality of psychiatric testimony would entail, among other things, a comparative analysis of trial transcripts under the Durham

122. 248 F.2d at 641 n.2.

123. For a dramatic illustration, see People v. Horton, 308 N.Y. 1, 20-22, 123 N.E.2d 609, 618-20 (1954) (Van Voorhis, J., dissenting).

124. "The purpose of employing an expert [psychiatric] witness is to obtain for the jury the benefit of his educated conclusions. He must give the jury the type of clinical opinion he is accustomed to form and to rely upon in the practice of his profession." Blunt v. United States, 244 F.2d 355, 364 (D.C. Cir. 1957).

125. Wechsler, The Criteria of Criminal Responsibility, 22 U. CHI. L. Rev. 367, 376 (1955).

126. Carter v. United States, 252 F.2d 608, 617 (D.C. Cir. 1957). 
rule with transcripts of cases tried in other jurisdictions under different tests of responsibility. ${ }^{127}$ Such studies, which are now in process, are beyond the scope of this paper. ${ }^{128}$ But a number of specific issues have arisen with respect to expert testimony which invite comment. For example, what is the probative significance under the Durham rule of testimony by a psychiatrist in response to such questions as, "Was this criminal act a product of mental disease or defect?" or, "Do the defendant's symptoms constitute a mental disease or a mental defect?"

\section{The "Product" Question}

Psychiatric experts who testify at the trial are commonly pressed by counsel to state, in the language of Durham, whether the alleged criminal act was the "product" of mental disease. ${ }^{129}$ This inquiry presents a conceptual difficulty for those psychiatrists who do not believe it is meaningful to separate a person's behavior from his psyche and to assert that some behavior is "caused"

127. A prominent psychiatrist who "stud[ied] the trial records as well as the appellate opinions" in some post-Durham decisions in the District, concluded as follows:

The most striking feature of the post-Durham insanity cases is the failure by nearly all psychiatric experts to utilize the new rule for its intended purpose. ... The testimony of most of the psychiatric experts continued to list classical symptoms of psychiatric syndromes, without discussing them from the standpoint of how they motivated or were related to the alleged criminal act. The records are replete with such words as "insanity," "psychosis," "schizophrenia," and "irresistible impulse," the peculiar clichéd idiom of this kind of case for more than 100 years. We find prosecution, and defense counsel frequently utilizing psychiatric language they obviously do not comprehend. Likewise, psychiatrists glibly use expressions like "incompetent," "unsound mind," and "insane"; legal words with no psychiatric or medical meaning. In short, discussions between psychiatrists and lawyers remained at the pre-Durham level, where stereotyped language, long since isolated from the roots of its legal or medical meaningfulness, continued as the principal vehicle for communication. Little if anything comprehensible or useful was conveyed to jury or judge in this manner, and their fact-finding about sanity, surely was due to impulse and chance, as often as it was to reason.

Watson, Durham Plus Five Years: Development of the Laze of Criminal Responsibility in the District of Columbia, 116 AM. J. Psychiarry 289-90 (1959).

128. Cf. James, Jurors' Assessment of Criminal Responsibility, 7 Soctal Problems 58 (1959). In connection with the University of Chicago jury project, Miss James analyzed the deliberations of panels of jurors who heard a recorded transcript of a trial presenting the insanity defense. Some panels were instructed in terms of the M'Naghten rule, others in terms of the Durham test. Some panels heard psychiatric testimony cast in technical, conclusory terms; other panels heard "model" psychiatric testimony. The deliberations were recorded with the knowledge of each panel. Findings published to date suggest that the nature of the offense itself (e.g., did the crime appear to be planned, was it a crime of violence) bulks larger in the jurors' deliberations than the expert testimony or the particular rule of responsibility.

129. See, e.g., Wright v. United States, 250 F.2d 4, 8 (D.C. Cir. 1957) ; Hopkins v. United States, 275 F.2d 155, 157 n.1 (D.C. Cir. 1959) ; Martin v. United States, 248 F.2d 217 (D.C. Cir. 1960). 
by a mental illness while other behavior is not. ${ }^{180}$ Some psychiatrists, on the other hand, accept a view of causation articulated in the Royal Commission Report on Capital Punishment and endorsed by the Court of Appeals :

Mental abnormalities vary infinitely in their nature and intensity and in their effects on the character and conduct of those who suffer from them. Where a person suffering from a mental abnormality commits a crime, there must always be some likelihood that the abnormality has played some part in the causation of the crime; and, generally speaking, the graver the abnormality, the more probable it must be that there is a causal connection between them. But the closeness of this connection will be shown by the facts brought in evidence in individual cases and cannot be decided on the basis of any general medical principle. ${ }^{131}$

In other words, the question of causal connection requires a judgment on the specific facts in each case. It may be a question of considerable complexity, since an answer requires a diagnosis of the accused's mental condition as of a date previous to the psychiatric examination, and a judgment as to what effect the disorder had on the accused's conduct at that time. If the illness is cyclical in character and marked by great fluctuations in intensity, ${ }^{132}$ and if a substantial interval has elapsed since the crime, a definitive answer may be impossible. One judge has caustically described this process as "antegnosis." 133 However, the necessity for ascertaining the defendant's mental condition at a point in the past-on the date of the offense-is not unique to Durham. ${ }^{134}$ It is also a feature of the M'Naghten and irresistible impulse tests. These two tests do not require an explicit judgment as to causation, but a judgment as to that issue is at least implicit in the uncontrollable impulse formula.

A leading critic of the Durham test, Professor Herbert Wechsler of Columbia University, Chief Reporter for the Model Penal Code, has argued that Durham is fatally defective as an administrable standard because of the logical ambiguity of the "product" concept. ${ }^{135} \mathrm{He}$ argues in substance that if the Durham rule means that a defendant is exempt if he would not have com-

130. Cf. Szasz, Psychiatry, Ethics, and the Criminal Law, 58 Colum. L. REv. 183 (1958).

131. Report of the Royal Cominssion, op. cit. supra note 51, at 99. The excerpt in the text has been twice quoted with approval by the Court of Appeals. Durham v. United States, 214 F.2d 862, 875 n.49 (D.C. Cir. 1954); Blocker v. United States, 274 F.2d 572, 573 (D.C. Cir. 1959).

132. A manic depressive disorder, for example, is "marked by severe mood swings, and a tendency to remission and recurrance." Amferican Psychiatric Ass'N, Diagnostic and Statistical Manual, Mentai Disorders 25 (1952).

133. Wright v. United States, 250 F.2d 4, 15 (D.C. Cir. 1957) (Miller, J., dissenting).

134. Cf. Goldstein \& Katz, Dangeroulsness and Mental Illness: Some Observations on the Decision to Release Persons Acquitted by Reasan of Insanity, 70 Y ALE L.J. 225, 229 n.17 (1960).

135. Wechsler, The Criteria of Criminal Responsibility, 22 U. CHI. L. Rxv. 367 (1955) ; Address, "Law, Morals and Psychiatry: Old Problems and Recent Reassess- 
mitted the act "but for" the illness, it would embrace too many persons; it could be construed to cover every case where mental disease is present. On the other hand, Wechsler maintains, if the Durham formula means that the crime must be the product of the illness in the sense of complete exclusion of volition by the defendant, then Durham represents no advance over the right and wrong rule.

The Court of Appeals, responding in effect to this line of criticism, has explained that there must be proof that the illness "critically" or "decisively" affected the defendant's behavior:

When we say the defense of insanity requires that the act be a 'product of' a disease, we mean that the facts on the record are such that the trier of the facts is enabled to draw a reasonable inference that the accused would not have committed the act he did commit if he had not been diseased as he was. There must be a relationship between the disease and the act, and that relationship, whatever it may be in degree, must be, as we have already said, critical in its effect in respect to the act. By 'critical' we mean decisive, determinative, causal; we mean to convey the idea inherent in the phrases 'because of', 'except for', 'without which', 'but for', 'effect of', 'result of', 'causative factor' ; the disease made the effective or decisive difference between doing and not doing the act. The short phrases 'product of' and 'causal connection' are not intended to be precise, as though they were chemical formulae. They mean that the facts concerning the act are such as to justify reasonably the conclusion that 'But for this disease the act would not have been committed.' 130

Not surprisingly, the testimony with respect to causation has covered a broad spectrum in some cases. In Martin $v$. United States, ${ }^{137}$ for example, six psychiatrists and a psychologist testified as to the accused's mental condition. One psychiatrist stated that if the accused were psychotic at the time of the offense, the crime would "of necessity" be a product of the illness. Another testified that a causal connection between the illness and the crime was "possible," still another felt the connection "probable," and a fourth was willing to say that there was a "strong probability" of a connection. An expert called by the government, who diagnosed the defendant as a sociopathic personality, expressed the opinion that there was "probably no connection." Each of these opinions was carefully qualified. ${ }^{138}$ In these circumstances, it was held that the product question was properly an issue to be resolved by the jury.

Prosecuting attorneys on occasion have complained that where there is substantial proof of mental illness they have encountered difficulty in obtaining experts who are willing to testify, on rebuttal, that the crime was not the

ments," Annual Meeting of the New York Society for Clinical Psychiatry, Jan. 15, 1959. See also Model Penal Cone $\$ 4.01$, comments at 159 (Tent. Draft No. 4, 1955); N.Y. Gov. Conference on Insanity, Interim Report of the Study Committee, May 29, 1958 (mimeographed text).

136. Carter v. United States, 252 F.2d 608, 617 (D.C. Cir. 1957).

137. Martin v. United States, 284 F.2d 217 (D.C. Cir. 1960).

138. Id. at 5 . 
product of the sickness. ${ }^{139}$ But Durham allows the prosecution alternative routes. It can prevail by proving either that the defendant was not mentally diseased, or that the criminal act was not the product of the disease. And in the great majority of cases, the issue is basically whether the accused suffered from a mental disease.

Part of the confusion over the "product" issue stems from the misconception that it is essentially a psychiatric question to be resolved by mental health experts. It is not. Whether the criminal act is so critically related to the mental illness as to exempt the defendant from responsibility is a jury question to be decided on the basis of the entire record, of which the psychiatric testimony is only a part. "The ultimate inferences vel non of relationship of cause and effect, are for the trier of the facts." 140

\section{Is the Illness a Disease?}

The psychiatric experts are also commonly asked, in the language of the test put to the jury, whether the symptoms described by them constitute a "mental disease" or a "mental defect." This form of question has led to considerable controversy.

There is a fundamental difference between asking a psychiatrist whether the accused is mentally diseased, and asking the jury to decide the same question. The psychiatrist is asked to express an opinion as to a question bearing upon medical classification and terminology. Psychiatrists who may agree as to symptoms and even as to the diagnosis, may disagree as to whether a particular disorder should be classified as a disease. The jury, on the other hand, is called upon to decide the ultimate issue of responsibility. Its province is to determine whether the defendant is so mentally diseased that he should be exempt from punishment. ${ }^{141}$

Failure to heed these distinctions led to an extraordinary episode in the District involving a change in psychiatric classification. Shortly after the Durham case was decided, the St. Elizabeths Hospital authorities concluded that sociopaths should not be classified as mentally diseased. ${ }^{142}$ Subsequent to this decision the institution's staff psychiatrists, who appear in most of the criminal cases in the District where sanity is an issue, usually testified to that effect when called as witnesses. In November 1957, after extensive consideration, the hospital staff changed its view: " $[\mathrm{P}]$ eople suffering from sociopathic personality disturbance should be 'labelled' as diseased, as mentally ill . . ." 143 This switch led the Court of Appeals to set aside a conviction for first degree

139. See Gasch, Prosecution Problems Under the Durham Rule, 5 Catmolic Law. 5, 21, 26 (1959) ; Report of Committee on Criminal Responsibility, 26 J.D.C. BAR Ass'N 301, 309-10 (1959).

140. Carter v. United States, 252 F.2d 608, 617 (D.C. Cir. 1957).

141. Briscoe v. United States, 248 F.2d 640, 644 (D.C. Cir. 1957) (Bazelon, J.).

142. $I d$. at 644 n.6.

143. Blocker y. United States, 274 F.2d 572, 573 (D.C. Cir. 1959). 
murder involving a sociopath who had been tried before November 1957. 144 $^{4}$ The St. Elizabeths' psychiatrists had testified at the trial, in accordance with the opinion then prevailing, that although the accused was a sociopath he was not mentally diseased. While an appeal was pending, the hospital staff changed its view as to the classification of sociopathic personality disturbances. In ordering a new trial, the Court of Appeals observed that the defendant. "his life at stake, was entitled to a verdict based upon the most mature expert opinion available on an issue vital to his defense." 145

This change in psychiatric opinion, and the ensuing reversal of the conviction, provoked sharp criticism of the Durham formula. ${ }^{146}$ It was argued that determination of responsibility had been abdicated by the courts to medical specialists whose views are in constant flux.

There are some who believe that the vice of testimony by psychiatrists in the ultimate language of the test can be eradicated only by abolishing the Durham rule. ${ }^{147}$ But the problem can be resolved by less drastic measures: either by forbidding psychiatrists to testify in terms of the test itself, or by appropriate instructions to the jury. The objection to restricting psychiatrists in this manner is that the Durham rule is designed precisely to eliminate artificial testimonial restrictions, and the limitation might well handicap an expert in communicating his opinion.

If psychiatrists are allowed to testify whether symptoms constitute a "disease," the jury must be carefully instructed that in applying the Durham test it may accept or reject expert testimony-that it is not deciding whether the defendant should be considered "diseased" for medical purposes. The court should make plain that the jury renders what Durham itself characterized as a "moral judgment," or, in any event, a judgment of a highly complex nature in which the medical testimony is only one of many operative factors. As one District Judge has aptly put it:

[W] hether a given defendant's condition amounts to a 'mental disease' is a question of fact which is determined by a trier [of fact] after asking some questions which are particularly medical in orientation, and other questions which may not be necessary to a strictly medical diagnosis. ${ }^{148}$

\section{The Presumption of Sanity and Burden of Proof Under the Durham Rule}

Neither the Durham opinion nor subsequent decisions by the D.C. Court of Appeals have altered the familiar rules, applied in all federal courts, that an accused person is presumed to be sane, that the duty of producing evidence

144. Ibid.

145. Ibid.

146. Report of Committee on Criminal Responsibility, 26 J.D.C. BAR Ass'N 301, 30607 (1959).

147. Blocker v. United States, No. 15777, D.C. Cir., March 3, 1961 (Burger, J., concurring).

148. United States v. Amburgey, D.D.C., Criminal Action No. 144-60, Nov. 30, 1960 (Youngdahl, J.). 
of insanity rests in the first instance upon the defendant, and that once sanity is in issue the prosecution has the ultimate burden of proving beyond a reasonable doubt that the accused is sane. ${ }^{149} \mathrm{New}$ content has been given to these rules, however, by the Court of Appeals. The thrust of the court's decisions is that the prosecution bears an especially heavy responsibility for producing expert evidence on the insanity issue. ${ }^{150}$ The opinions addressed to these problems reflect recognition that most criminal defendants are paupers or penniless vagrants, uneducated, and represented by court appointed counsel who serve without a fee, and that the government has at its disposal extensive psychiatric facilities and investigative resources.

\section{The Presumption of Sanity}

An accused who claims that he was not responsible has the initial duty of introducing "some evidence" showing that he suffered from a mental disease or defect at the time of the offense. ${ }^{151}$ The defendant is not required to show that the crime was the product of mental illness in order to place insanity in issue. ${ }^{152}$ Thus, one who offers "some evidence" of unsound mind in effect obtains the benefit of a presumption of fact that there is a causal connection between his illness and his allegedly criminal behavior. ${ }^{153}$ However, if the prosecution presents testimony to the effect that the crime was not the product of the illness, the defendant may be obliged on rebuttal to present contradictory evidence in order to prevail with the jury.

It is obviously impossible "to formulate a quantitative measure of the amount of evidence necessary" to satisfy the "some evidence" requirement. ${ }^{154}$ The quantum will vary from case to case. In general, however, trial courts have been liberal in permitting the insanity issue to go to the jury. The Durham test has been submitted to the jury where there is "a bare minimum of evidence of insanity." 155 For example, a jury was permitted to consider the defendant's responsibility where the only evidence of insanity consisted of a declaration by the defendant on the witness stand that "I did this crime un-

149. Davis v. United States, 160 U.S. 469,488 (1895); Rivers v. United States, 270 F.2d 435, 439 (9th Cir. 1959), cert. denied, 362 U.S. 920 (1960) ; Carter v. United States, 252 F.2d 608, 614-15 (D.C. Cir. 1957) ; Douglas v. United States, 239 F.2d 52, 55 (D.C. Cir. 1956).

150. See Blunt v. United States, 244 F.2d 355, 364 n.23 (D.C. Cir. 1957).

151. [I]n criminal cases the defendant is entitled to have presented instructions relating to a theory of defense for which there is any foundation in the evidence, even though the evidence may be weak, insufficient, inconsistent, or of doubtful credibility. Tatum v. United States, 190 F.2d 612, 617 (D.C. Cir. 1951). See also Durham v. United States, 214 F.2d at 875; Logan v. United States, 284 F.2d 238 (D.C. Cir. 1960).

152. See United States v. Amburgey, D.D.C., Crim. Action No. 145-60, Nov. 30, 1960.

153. See excerpt from Report of the RoYal CoMmission, op. cit. supra note 51 (quoted in text at note 131 supra).

154. Tatum v. United States, 190 F.2d 612, 615 (D.C. Cir. 1951).

155. Bailey v. United States, 248 F.2d 558, 561 (D.C. Cir. 1957), cert. denied, 355 U.S. 919 (1958). 
beknowing to what I was doing ... I believe I was insane, out of my head" on the night of the shooting. ${ }^{156}$ And the Court of Appeals set aside one conviction because of a failure to charge the jury on insanity where the defendant, an alcoholic charged with taking indecent liberties with a child, testified that he had delusions and heard voices. ${ }^{157}$ In the usual case in which an accused claims that he was of unsound mind at the time of the offense, the evidence adduced by the defendant in discharging his duty of going forward consists of testimony by psychiatric experts, testimony by laymen who know the accused intimately and have observed abnormal conduct, ${ }^{158}$ and evidence of previous confinement in mental hospitals. Thus, a trial court was held not to have erred in refusing to give an insanity instruction where there was no evidence by experts of mental abnormality, no testimony by any lay witness of irrational conduct by the defendant, and the only evidence pertinent to the issue was testimony of the defendant himself that he remembered nothing of the crime. ${ }^{15 \theta}$

\section{The Burden of Proof}

Once insanity has been put in issue by some evidence of mental disease or defect, the prosecution can prevail only if it establishes beyond a reasonable doubt either that the defendant had no mental disease or defect, or that the crime was not the product of mental illness. ${ }^{160}$ Thus, if the government cannot prove that the defendant was of sound mind, it can prevail by showing the absence of a causal relationship between the illness and the act.

A striking indication of the extent to which the government is held to its burden is shown by the fact that on five separate occasions since Durham, the Court of Appeals has taken the unusual step of reversing a conviction on the grounds that the trial court should have set aside a jury verdict and directed a verdict of not guilty by reason of insanity because the prosecution failed to prove sanity beyond a reasonable doubt. ${ }^{101}$ In each case, the expert psychiatric testimony offered by the defense was substantial and persuasive. The

156. Clark v. United States, 259 F.2d 184, 186 (D.C. Cir. 1958) (dissenting opinion). This liberal interpretation of the "some evidence" requirement was made in a capital case. Compare Smith v. United States, 272 F.2d 547 (D.C. Cir. 1959).

157. Goforth v. United States, 269 F.2d 778 (D.C. Cir. 1959).

158. Carter v. United States, 252 F.2d 608, 618 (D.C. Cir. 1956); see Kelley v. Únited States, 236 F.2d 746, 747-48 (D.C. Cir. 1956).

159. Wright v. United States, 215 F.2d 498 (D.C. Cir. 1954). See also Smith v. United States, 270 F.2d 921 (D.C. Cir. 1959) ; Lebron v. United States, 229 F.2d 16 (D.C. Cir. 1955 ).

160. Carter v. United States, 252 F.2d 608, 615 (D.C. Cir. 1956) ; Wright v. United States, 250 F.2d 4, 7 (D.C. Cir. 1957); Douglas v. United States, 239 F.2d 52, 55 (D.C. Cir. 1956).

161. Isaac v. United States, 284 F.2d 168 (D.C. Cir. 1960) ; Satterwhite v. United States, 267 F.2d 675 (D.C. Cir. 1959) ; Fielding v. United States, 251 F.2d 878 (D.C. Cir. 1957) ; Wright v. United States, 250 F.2d 4 (D.C. Cir. 1957) ; Douglas v. United States, 239 F.2d 52 (D.C. Cir. 1956). See also Hopkins v. United States, 275 F.2d 155 (D.C. Cir. 
prosecution, on the other hand, relied either exclusively on the testimony of laymen who did not know the defendant intimately-the victim of a robbery, witnesses to the crime, the policeman who made the arrest-or upon experts who did not contradict testimony by defense experts that the defendant suffered from a mental disease or defect. The practical import of these decisions is that the prosecution must assume the responsibility of producing either laymen who have been closely associated with the defendant for a long period of time, or experts who are prepared to affirm that the defendant was not suffering from a mental disease or defect at the time of the offense.

The Court of Appeals has recognized a distinction between testimony as to the defendant's mental condition by laymen who have had only brief contact with the accused (e.g., the arresting officer) and laymen who have been associated with the defendant on intimate terms for a prolonged period (e.g., a spouse or relatives). Testimony by a casual acquaintance to the effect that the defendant appeared to be of sound mind is obviously of slight value, though testimony by such a witness that he observed abnormal behavior would be of considerable probative importance. ${ }^{162}$ On the other hand, testimony by a close associate of the defendant of many years standing obviously is entitled to substantial weight, whether it is to the effect that the accused behaved normally or otherwise.

The importance of these distinctions is reflected in the rules which have emerged with respect to the burden of proof.

1. If qualified psychiatrists disagree with respect to the defendant's sanity at the time of the offense, the issue should be resolved by the jury, and its verdict will not be disturbed. ${ }^{163}$

2. If the expert psychiatric testimony offered on behalf of the accused is equivocal or ambiguous, and contradictory testimony by laymen—particularly those who have been long and intimately associated with the defendant-is substantial and credible, the issue should be left to the jury. ${ }^{164}$

3. If the expert testimony on behalf of the accused is extensive and impressive, the government does not discharge its burden of proof by the testimony of arresting officers or laymen who have had only brief contact with the accused; in the absence of contradictory testimony by qualified experts or long

1959)' (verdict by court sitting without jury reversed because government failed to satisfy burden of proof on sanity issue).

162. Carter v. United States, 252 F.2d 608, 618 (D.C. Cir. 1956) ; Hopkins v. United States, 275 F.2d 155, 157 (D.C. Cir. 1959).

163. Starr v. United States, 264 F.2d 377, 379 (D.C. Cir. 1958), cert. denied, 359 U.S. 936 (1959) ; Jordan v. United States, 217 F.2d 670 (D.C. Cir. 1954); cf. Jones v. United States, 284 F.2d 245 (D.C. Cir. 1960). See also Dukes v. United States, 278 F.2d 262 (D.C. Cir. 1960) (case was properly submitted to jury when government psychiatrist said there was no causal connection while defendant's expert said he was unable to offer an opinion on this point).

164. Bradley v. United States, 249 F.2d 922 (D.C. Cir. 1957); Kelley v. United States, 236 F.2d 746 (D.C. Cir. 1956). 
time intimates of the defendant, the trial court should direct a verdict of not guilty by reason of insanity. ${ }^{165}$

\section{Instructions to the Jury}

Juries are typically charged in the exact language of the Durham opinion itself, as supplemented by the gloss placed upon the "product" portion of the rule in Carter $v$. United States. ${ }^{\mathbf{1 6 0}}$ In addition, the jury must be told in substance that if the defendant is acquitted by reason of insanity, he will be hospitalized until the hospital authorities and the courts are satisfied that he has recovered his sanity and that he will not be dangerous to himself or others if released. ${ }^{167}$ This instruction may have an enormous influence on the jury's deliberations, and it is clearly one of the most important developments in this field since Durham itself.

The disposition of the defendant following the verdict is theoretically of no concern to the jury; its function is to determine guilt or innocence. A jury, however, commonly knows the consequences of a guilty or not guilty verdict. Jurymen are typically aware that unless probation is granted a defendant who is found guilty may be executed, imprisoned, or fined. ${ }^{168}$ The consequences of a verdict of not guilty by reason of insanity, however, are not commonly understood. The jury does not usually know that a defendant who is acquitted on insanity grounds will be confined in a mental institution. In the absence of this knowledge, "a jury, influenced by the specter of violent lunatics turned loose in the community, may 'convict despite strong evidence of insanity at the time of the crime." 160

These considerations prompted the Court of Appeals to hold shortly after Durham that in a trial involving an insanity defense "counsel may and the judge should inform the jury that if [the defendant] is acquitted by reason of insanity he will be presumed to be insane and may be confined in a 'hospital for the insane' as long as 'the public safety and ... [his] welfare' requires." 170 Failure to give this instruction was not, however, held to be reversible error, and some district judges adhered to the view that the instruction was not obligatory in all cases, particularly if the defendant did not request it. ${ }^{171}$

165. See cases cited note 161 supra.

166. 252 F.2d 608 (D.C. Cir. 1956); see text at note 136 supra.

167. Lyles v. United States, 254 F.2d 725, $728-29$ (D.C. Cir. 1957), cert. denied, 356 U.S. 961 (1958).

168. "The jury was fully aware of the fact that in the District of Columbia the punishment of murder in the first degree is death by electrocution ...." Blocker v. United States, 274 F.2d 572, 575 (D.C. Cir. 1959) (dissenting opinion).

169. Tatum v. United States, 249 F.2d 129, 133 (D.C. Cir. 1957), cert. denied, 356 U.S. 943 (1948) (dissenting opinion); see Howard v. United States, 229 F.2d 602, 608

(5th Cir. 1956) (dissenting opinion), rev'd on rehcaring en banc, 232 F.2d 274 (1956).

170. Taylor v. United States, 222 F.2d 398, 404 (D.C. Cir. 1955).

171. See Tatum v. United States, 249 F.2d 129, 132-33 (D.C. Cir. 1957), cert. denied, 356 U.S. 943 (1958). 
In 1955, Congress enacted legislation requiring compulsory hospitalization in all cases where a defendant is acquitted on insanity grounds. ${ }^{172}$ The statute itself does not require that the jury be apprised of the defendant's fate in the event of an insanity verdict. But subsequent to passage of this legislation, the Court of Appeals concluded that in all cases where the insanity issue is submitted to the jury, trial courts must inform juries of the disposition which will be made of the defendant. ${ }^{173}$ Failure to so instruct a jury would today constitute grounds for reversal in the District.

\section{The Entry of a Verdict of Not Guilty by Reason of Insanity Over the Defendant's Objection}

Assuming that a defendant is found competent to stand trial, may a trial judge disregard a plea of guilty and substitute a verdict of not guilty by reason of insanity over a defendant's objection? This question has arisen in the District of Columbia in proceedings involving persons who are charged with petty offenses, such as disorderly conduct or passing bad checks, which bear a short prison term upon conviction. ${ }^{174}$ As discussed below, a verdict of not guilty because of insanity results in commitment until the defendant establishes that he is free from an "abnormal mental condition" which renders him dangerous, that is, in confinement for an indefinite period. For this reason, some defendants have sought to plead guilty and have strenuously resisted a verdict of not guilty by reason of insanity.

The trial judge may be alerted to the possibility that the defendant was of unsound mind at the time of the offense by the psychiatric report transmitted to the court in connection with proceedings to determine fitness to stand trial. That report may contain a psychiatric opinion to the effect that the crime was the product of mental disease. In a recent case ${ }^{175}$ the Court of Appeals concluded that in these circumstances a trial judge has discretion to reject a guilty plea and, if the evidence so warrants, to find the defendant not guilty by reason of insanity, not withstanding the defendant's objection.

The argument in favor of the exercise of this power runs along the following lines. First, it is not obligatory upon a trial court to accept a guilty plea; there are appropriate circumstances when such a plea may be disregarded.178 Indeed, a trial judge cannot conscientiously overlook evidence of insanity. There is "almost a positive duty on the part of the trial judge not to impose

172. D.C. CoDe ANn. § 24-301 (d) (Supp. VIII, 1960).

173. - Lyles v. United States, 254 F.2d 725 (D.C. Cir. 1957), ccrt. denticd, 346 U.S. 901 (1958).

174. See Overholser v. Iynch, No. 15,859 , D.C. Cir., Jan. 26 , 1961 ; Williams v. District of Columbia, 147 A.2d 773 (D.C. Mun. Ct. App. 1958) ; Williams v. Overholser, 259 F.2d 175 (D.C. Cir. 1958). See also The Washington Post \& Times Herald, Jan. 30, 1961, p. B1, col. 2.

175. Overholser v. Lynch, supra note 174.

176. See, e.g., United States v. Trinder, 1 F. Supp. 659 (D. Mont. 1932). 
a criminal sentence on a mentally ill person." ${ }^{177}$ Second, the public, as well as the accused, has a legitimate interest in the principle that a person who is mentally diseased at the time of the offense should not be held criminally responsible. A defendant of unsound mind should not receive a short sentence of imprisonment which leaves him free in a brief time to commit further criminal acts; the public safety, as well as the welfare of the accused, requires that he be hospitalized until reasonable assurance can be given that he will not be dangerous. "Society has a stake in seeing to it that a defendant who needs hospital care does not go to prison." 178

Forceful arguments can be marshaled, however, against compelling a defendant to stand trial on the insanity issue. If an individual is competent to stand trial, by definition he is competent to submit any permissible plea. Although it is true that a "court may refuse to accept the plea of guilty," ${ }^{179}$ such pleas are almost invariably received in noncapital cases if the accused is represented by counsel and if it is clear that the plea has been "made voluntarily after proper advice and with full understanding of the consequences." 180 Moreover, in the typical case where a guilty plea is rejected, a defendant is discharged if found not guilty. However, if a defendant is acquitted by reason of insanity, he is hospitalized until he is sane and no longer dangerous. The consequences of refusal to accept a guilty plea are, therefore, radically different if a trial on an insanity issue ensues.

The accused's privilege to enter a guilty plea is intimately associated with his constitutional right to counsel. The defendant may have been counseled to enter a guilty plea in the expectation that a less severe sentence will be imposed, or in order to avoid a public trial. On the other hand, a defendant may have been advised to plead guilty because of counsel's belief that the rigorous standards for release from hospital confinement can never be satisfied by the accused. ${ }^{181} \mathrm{~A}$ trial court's refusal to accept a guilty plea may, thus, seriously compromise the right to effective assistance by counsel.

An extraordinary inversion of the usual roles of the prosecution and the defense results if the trial court rejects a guilty plea and then receives evidence bearing on the accused's mental condition as of the date of the offense. The defense insists in such circumstances that the accused was sane at the time of the offense, and that he is guilty; the prosecution; in a reversal of its customary position, undertakes to show that the accused was of unsound mind, that the crime was the product of a mental disease, and that the defendant is not guilty by reason of insanity. The rules as to burden of proof in this situation have not been delineated. Presumably, the usual rules respecting the burden of proof are applicable; that is, the defendant will be adjudged not guilty by reason of in-

177. Overholser v. Lynch, No. 15,859, D.C. Cir., Jan. 26, 1961, at 8.

178. Id. at 9 .

179. FED. R. CRIM. P. 11.

180. Kercheval v. United States, 274 U.S. 220, 223 (1927); High v. United States, No. 15996, D.C. Cir., March 2, 1961.

181. See text at notes $215-17$ infra. 
sanity if there is a reasonable doubt that he was mentally diseased at the time of the crime. Hence, the accused cannot prevail unless he proves that he was sane.

The rules relating to burden of proof, however, are designed to reflect the greater resources and superior investigative facilities available to the prosecution. A defendant, who is commonly indigent, ordinarily lacks the resources to disprove what is in effect a charge of mental disease. For example, he may not possess sufficient funds to retain a nongovernment psychiatrist as an expert witness. In brief, forcing a defendant to stand trial on an insanity issue shoulders him with an evidentiary burden which he is seldom equipped to meet.

These objections as to the evidentiary burden would be partially mitigated if a rule were adopted-applicable only to the situation where a guilty plea is rejected-that a defendant is sane if there is reasonable doubt as to his sanity. If insanity were not proved beyond a reasonable doubt, the guilty plea could be reinstated, or the defendant could be allowed to plead not guilty.

Finally, the community's interest in the hospitalization of mentally ill offenders is not completely sacrificed if the accused's guilty plea is accepted and he is sentenced to imprisonment. If the defendant, though competent to stand trial, requires treatment for his mental condition, he can be transferred by the prison authorities to a mental institution for as long as the duration of his sentence. ${ }^{182} \mathrm{It}$ is, however, true that the period required for treatment is not necessarily commensurate with the sentence. But if the individual is mentally ill and dangerous at the expiration of his sentence, civil commitment proceedings can be initiated. ${ }^{183}$

One aspect of this controversy touches upon the obligations of counsel toward a person accused of a criminal offense. Counsel, frequently court appointed, may know that the accused suffered from a mental disease; but the defendant may insist that a plea of guilty be entered, and that no disclosure be made of his mental condition. If, as the Court of Appeals has stated, there is "almost a positive duty" by a trial judge not to punish a mentally ill person, can counsel-who is an officer of the court-withhold information which could frustrate the performance by the court of its judicial duty? Can an attorney, who recommends a plea of insanity but is overruled by his client, withdraw his appearance without disclosing to the court the very facts which his client wishes suppressed? And should an attorney who conscientiously believes that the welfare of his client would best be served by a plea of guilty apprise the court of the accused's mental condition? These questions are currently unresolved in the District of Columbia.

\section{Postrrial Commitment and Release}

In its Durham opinion, the Court of Appeals defined a "mental disease" as a condition which is "considered capable of either improving or deteriorat-

182. 18 U.S.C. § 4241 (1958); D.C. CoDE ANN. § 24-302 (Supp. VIII, 1960); see Carter v. United States, 283 F.2d 200, 203 (D.C. Cir. 1960).

183. D.C. Code ANn. § 21-311 (1951). 
ing."184 The change in mental condition which can occur over a period of time is the empirical fact at the root of one of the most perplexing problems in the administration of the insanity defense: If a person who is acquitted on insanity grounds is hospitalized, under what circumstances should he be released?

The mental condition of an accused person may alter significantly in the time interval between the date of the offense and the jury's verdict. Thus, the defendant may have suffered from a severe mental disorder at the time of the crime-for example, an illness which would be clinically diagnosed as a psychosis. As a result of therapy, or because of other factors, he may subsequently experience sufficient remission or diminution in the symptoms of the illness, so that he becomes lucid. Indeed, the accused must be in sufficient contact with reality to be competent to stand trial. Yet during the trial the defendant may still be suffering from a severe mental illness which requires treatment and which would render him dangerous if released. On the other hand, it is by no means inconceivable that by the time of the verdict, a defendant who is found not guilty by reason of insanity as of the date of the offense, may have recovered sufficiently so that he would no longer be diagnosed as psychotic. If the defendant's mental condition at that point is such that he could not be involuntarily committed to a mental institution in a civil proceeding, under what theory can he be confined in such an institution if he is acquitted because he was mentally diseased when the crime was committed? Moreover, even if the defendant is of unsound mind at the time of the verdict, he may subsequently recover sufficiently so that he could be released without danger to the public or to himself. What should be the standard of release, and who should determine whether the defendant will be released ? $^{\mathbf{1 8 5}}$

When Durham was decided in 1954, it was discretionary with the trial courts in the District of Columbia whether a defendant acquitted by reason of insanity would be committed to a mental institution. ${ }^{186}$ Trial judges were empowered-but not required-to order hospitalization in such cases. While it was customary for persons found not guilty because of insanity to be committed as a matter of routine, ${ }^{187}$ it was at least theoretically possible for a defendant to be released scot free following such a verdict.

Apprehension that Durham would result in a flood of acquittals by reason of insanity and fear that these defendants would be immediately set loose led to agitation for remedial legislation. In 1955, Congress enacted a statute mak-

184. 214 F.2d at 875:

185. This question is thoughtfully discussed by Goldstein \& Katz, supra note 134.

186. The District of Columbia Code in 1954 provided in pertinent part as follows: "[I]f an accused person shall be acquitted by the jury solely on the ground of insanity, the court may certify the fact to the Secretary of the Department of Health, Education, and Welfare, who may order such person to be confined in the hospital for insane." D.C. Code Ann. $\$ 24-301$ (1951). (Emphasis supplied.) See Durham v. United States, 214 F.2d 862, 876 n.57 (D.C. Cir. 1954).

187. See Comsamtee on Mental Disorder as a Criminal Defense, Report to the Council on Law Enforcensent of the District of Columbia, in S. Rep. No. 1170, 84th Cong., 1st Sess. 5, at 12-13 (1955). 
ing hospitalization automatic and mandatory in every case tried in the District of Columbia where a defendant is found not guilty by reason of insanity. ${ }^{188}$

The primary legislative purpose was protection of the public safety. The statute is designed "to guard against imminent recurrence of some criminal act" by a person acquitted on insanity grounds who presumably is not significantly influenced in his conduct by punitive sanctions. ${ }^{189}$ But the statute also indirectly reinforces the vitality and integrity of the insanity defense. It discourages frivolous insanity pleas and, when brought to the attention of the jury, eliminates a factor which could seriously prejudice a meritorious insanity plea.

In addition to requiring compulsory hospitalization, the statute prescribes the conditions and procedure for release from hospital confinement. The issues discussed below have arisen in this connection.

\section{The Statutory Scheme}

The jury's verdict that the defendant is not guilty by reason of insanity is, of course, not a finding that the accused is insane at the time of the verdict. Indeed, it does not necessarily constitute a finding that the defendant was of unsound mind when the offense was committed; it may signify only that there was a reasonable doubt in the jurors' minds whether the accused was then mentally ill, a doubt which the prosecution failed to dispel. ${ }^{100}$ The statute contemplates, however, that every person acquitted on grounds of insanity shall automatically be committed to a mental institution. ${ }^{101}$ The act does not require a separate posttrial hearing or any finding with respect to the mental condition of the defendant as of the date of the verdict. ${ }^{192}$

188. D.C. Cone Ann. § 24-301(d) (Supp. VIII, 1960). There is no provision similar to the District of Columbia statute governing the conduct of trials in other federal courts; defendants found not guilty by reason of insanity are customarily set free. See Sauer v. United States, 241 F.2d 640, 651 (9th Cir. 1957), cert. denied, 354 U.S. 940 (1957). Sec also Guttmacher, Principal Difficulties with the Present Criteria of Responsibility and Possible Alternatives, Model PeNal Code $\$ 4.01$, app. B, at 171 (Tent. Draft No. 4, 1955). In some cases, a defendant found not guilty by reason of insanity in a federal court could be committed to a state mental institution in a civil commitment proceedings in a state court pursuant to applicable state law.

189. See note 187 supra.

190. See Ragsdale v. Overholser, 218 F.2d 943, 950 (D.C. Cir. 1960).

191. D.C. Cope Ann. $\$ 24-301$ (d) (Supp. VIII, 1960); Report of the Committee on Mental Disorder as A: Crininal Defense, op. cit. sipra note 187, at 12-13.

192. It has been urged that the statute be amended to provide, in cases where a person is found not guilty by reason of insanity, for a hearing, promptly after the trial, at which the question would be whether the defendant was presently "dangerously insane." Halleck, The Insanity Defense in the District of Colnmbia-A Legal Lorclei, 49 GEo. L.J. 294, 31819 (1960). Only "dangerously insane" individuals would be detained. Defendants who were not insane, i.e., sociopaths, and defendants who were insane but not dangerous, would be released if this procedure were followed. The constitutionality of the statute providing for automatic hospitalization without a posttrial hearing was upheld by the D.C. Court of Appeals in Ragsdale v. Overholser, 281 F.2d 943 (D.C. Cir. 1960). 
The statute authorizes unconditional and conditional releases from compulsory hospitalization. ${ }^{103}$ For an unconditional release the hospital superintendent must certify to the District Court that the defendant "(1) . . . has recovered his sanity, (2) that, in the opinion of the superintendent, such person will not in the reasonable future be dangerous to himself or others, and (3) in the opinion of the superintendent, the person is entitled to his unconditional release from the hospital . . ." "194 The court may authorize release on the basis of this certificate alone or, on its own initiative, the court may require a hearing to determine if the defendant "has recovered his sanity and will not in the reasonable future be dangerous to himself or others." A hearing must be held if the United States attorney objects to the release.

Conditional release may be authorized if the superintendent certifies that the defendant is fit "to be conditionally released under supervision."105 The court is vested with ultimate authority to determine whether, and under what conditions, probationary release will be allowed.

It should be noted that while the statute contemplates that release procedures will be initiated by the hospital superintendent, the committed person himself may apply for release by a petition for habeas corpus. ${ }^{196}$

\section{Iudicial Gloss on the Standard for Release}

The statutory release provisions have been strictly construed against parties seeking their freedom. The statute came before the D.C. Court of Appeals for the first time in a 1958 case, Overholser v. Leach. ${ }^{197}$ Leach was acquitted of robbery charges on grounds of insanity and was thereupon committed to St. Elizabeths Hospital. Five months after trial he filed a petition for a writ of habeas corpus, alleging that he was eligible for release from hospital confinement. In resisting the application, the hospital authorities asserted that they could not certify that Leach would not be dangerous to himself or others if he were discharged. At a subsequent hearing, seven psychiatrists testified. All agreed that Leach was a "sociopathic personality with dysocial outlook" and that he would be dangerous to the community if released. ${ }^{198}$ Five of the specialists took the view that Leach should be classified as mentally diseased; two of the psychiatrists, however, entertained the opinion that the illness was not a mental disease. The Court of Appeals concluded that in these circumstances Leach had failed to establish that the hospital authorities had acted arbitrarily in refusing to issue the statutory certificate, and accordingly that he was not entitled to release.

193. D.C. Code ANn. $\S 24-301$ (e) (Supp. VIII, 1960).

194. Ibid.

195. Ibid.

196. D.C. Code ANn. \$ 24-301 (g) (Supp. VIII, 1960); see Overholser v. Leach, 257 F.2d 667 (D.C. Cir. 1958), cert. denied, 359 U.S. 1013 (1959) ; Ragsdale v. Overholser, 281 F.2d 943, 948 (D.C. Cir. 1960) ; O’Beirne v. Overholser, No. 15,634, D.C. Cir., Nov. 23,1960 , at 6 .

197. 257 F.2d 667 (D.C. Cir. 1958), cert. denied, 359 U.S. 1013 (1959).

198. Id. at 669 . 
In the opinion as first announced the court formulated the standard governing release in these words:

The [statutory] phrase "establishing his eligibility for release" as applied to the special class of which Leach is a member, means something different from having one or more psychiatrists say simply that the individual is "sane". There must be freedom from such mental disease or defect as would make the individual dangerous to himself or the community in the reasonably foreseeable future. ${ }^{199}$

The test governing release as thus phrased-proof by the accused of "freedom from such mental disease or defect" as would render him dangerouswas made equivalent in a critical respect with the Durham test of responsibility. The release statute, however, does not use the phrase "mental disease or defect"; rather it is cast in terms of recovery of sanity and the dangerousness of the accused if released. The record in the Leach case disclosed the troublesome questions which would immediately arise if the Durham standard were assimilated to the release standard. The psychiatrists who testified in Leach were in disagreement as to whether Leach should be classified as "mentally diseased" although they all concurred in the diagnosis that he was a sociopathic personality and dangerous. Thus, use of the phrase "mental disease or defect" in the standard for release would invite disagreement among experts over a question of nomenclature, and would perpetuate a source of confusion which had provoked serious criticism of the Durham formula itself. ${ }^{210}$

The Court of Appeals subsequently amended its Leach opinion by deleting "mental disease or defect" and substituting the words "abnormal mental condition." 201 The revised standard governing release reads as follows:

There must be freedom from abnormal mental condition as would make the individual dangerous to himself or the community in the reasonably foreseeable future. ${ }^{202}$

The phrase "abnormal mental condition" was obviously chosen with meticulous care, and was manifestly designed to reach the case of a sociopath acquitted on grounds of insanity who, though "sane" and not mentally diseased in the terminology of some specialists, may suffer from an emotional disorder which makes him dangerous. Indeed, "abnormal mental condition" is a sufficiently comprehensive standard to reach all types of mental disorders. Thus, in one recent case, release was denied to a person diagnosed as suffering from a "psychoneurotic reaction, obsessive compulsive reaction." In the opinion of one psychiatrist, the patient would have been "dangerous to society because of his checkwriting proclivity" were he released. ${ }^{203}$

199. Opinion of Court entered July 10, 1958, Overholser v. Leach, No. 14,480, D.C. Cir. (not reported).

200. See text at notes $142-48$ supra.

201. Order, Overholser v. Leach, No. 14,480, D.C. Cir., Sept. 18, 1958; 25 J.D.C. BAK Ass'N 582 (1958).

202. Order, supra note 201. (Emphasis added.)

203. Overholser v. Russell, 283 F.2d 195 (1960). 
By construing the statute to require proof of freedom from an "abnormal mental condition" as a precondition to release, the Court of Appeals significantly broadened the class of persons who can be detained from among those found not guilty by reason of insanity. The court made it possible to confine persons who are "sane" in the colloquial sense, e.g., sociopaths and those suffering from psychoneurotic disorders. But on what theory can a "sane" person be detained in a mental institution, even assuming that he suffers from an "abnormal mental condition" and that he would be dangerous if released? The Court of Appeals has reasoned that such persons are in an "exceptional class"- they are "people who have committed acts forbidden by law, who have obtained verdicts of 'not guilty by reason of insanity', and who have been committed to a mental institution pursuant to the [mandatory commitment statute]."204 The shortcoming of this response is that hospitalization of persons acquitted by reason of insanity is not intended as punishment-it is designed for treatment and rehabilitation 205_ and to detain a "sane" person in a mental institution is plainly punitive. In addition, the argument that such persons can be confined to protect the public because they may be potentially dangerous will not withstand the slightest scrutiny. To deprive a person of liberty because of "evil or criminal propensities he may be thought to have" would offend due process; it "would transform the hospital into a penitentiary where one could be held indefinitely for no convicted offense."206 A defendant found guilty and imprisoned cannot be futher detained after he has served his sentence, even though there may be every indication that he will repeat his antisocial behavior following release. ${ }^{207}$

Various solutions have been proposed for this problem. It has been suggested that under the statutory standard for release-_"dangerousness to himself or others" in the reasonable future-the government should be unable to detain a defendant acquitted on insanity grounds if it cannot prove that there is a reasonable likelihood that upon his release from hospitalization he will engage in an offense involving physical danger to persons or property. ${ }^{208}$ In other words, greater leniency would be shown to those acquitted of petty or nonviolent offenses by reason of insanity. Thus, a defendant found not guilty of a shoplifting or a bad check charge because of a mental disease would be released, after a brief period of observation, if he were then of sound mind, even though there might be expert testimony that he would probably engage in

204. Overholser v. Leach, 257 F.2d 667, 669-70 (D.C. Cir. 1958), cert. denied, 359 U.S. 1013 (1959).

205. "'Rehabilitation' and 'restoration to usefulness': These considerations have been prime movers in the development of our present law of criminal insanity ...." Overholser v. Lynch, No. 15,859, D.C. Cir., Jan. 26, 1961, at 7-8. ing).

206. Ragsdale v. Overholser, 281 F.2d 943,950 (D.C. Cir. 1960) (Fahy, J., concurr-

207. See In re Williams, 157 F. Supp. 871,876 (D.D.C. 1958).

208. Ragsdale v. Overholser, 281 F.2d 945, 950-51 (D.C. Cir. 1960) (Fahy, J., concurring) ; Overholser v. Lynch, No. 15,859, D.C. Cir., Jan. 26, 1961 (Fahy, J., dissenting). 
the same unlawful conduct once he was discharged. The principal technical difficulty with this thesis is that Congress directed mandatory commitment of all persons acquitted by reason of insanity for any "offense," without qualification; the release statute, apart from its use of the term "dangerous," does not classify or differentiate among different types of offenses as a standard of release. Moreover, this view would sanction continued confinement in a mental institution of the "sane" offender who predictably would engage in dangerous conduct if he were discharged from the hospital.

It has also been suggested that Congress should amend the statute to provide for release simply upon proof that the party has recovered his sanity. ${ }^{200}$ This solution, however, simply bypasses the danger of abuse of the insanity defense under a broad rule such as Durham; it would result in the discharge of all individuals acquitted on grounds of insanity who are not psychotic. Sociopaths and individuals suffering from psychoneurotic disorders-who are not considered "insane"-could not be detained even if dangerous to themselves or others. This proposal could result in precisely the abuse of the insanity defense which the present release statute was designed to prevent, and it could result in seriously discrediting the insanity defense in the public mind.

The test of continued detention could be made equivalent with the standard for involuntary civil commitment, i.e., a person must be shown to be "insane or of unsound mind," incapable of managing his affairs, dangerous if left at large, and "a fit subject for treatment." psychotic defendants are frequently committed-for example, homicidal and suicidal persons. Acceptance of this standard, therefore, would not necessarily lead to release of all persons diagnosed to be nonpsychotic, so that "sane" persons could be detained in a mental institution.

In short, none of the solutions advanced is free from difficulty. Any test must necessarily reconcile the right of the public to protection from persons who by definition have not been deterred by the usual criminal sanctions, and the right of the individual to be free from confinement because of alleged evil propensities, a notion fundamental to Anglo-Saxon criminal justice.

It is now settled in the District that if a defendant is deemed to be dangerous but is not suffering from any "abnormal mental condition" he cannot be detained in a mental institution.211 "His dangerous tendencies must be attributed to an abnormal mental condition if he is to be retained in confinement . . .."212 Conversely, if the defendant suffers from an abnormal mental condition, but is not dangerous-for example, if he has not recovered his sanity but is not dangerous-he may be eligible for conditional release. ${ }^{213}$

209. See Goldstein \& Katz, supra note 134, at 239.

210. D.C. CoDe Ann. \$ 21-311 (1951).

211. Starr v. United States, 264 F.2d 377, $382-83$ (D.C. Cir. 1958), cert. denied, 359 U.S. 936 (1959).

212. Ibid.

213. Hough v. United States, 271 F.2d-458-(D.C. Cir. 1959). 


\section{Summary of Procedural and Evidentiary Problems in Release Proceedings}

The inmate who seeks release must discharge a heavy burden. ${ }^{214} \mathrm{He}$ must show (i) that he does not suffer from an abnormal mental condition; (ii) that in the reasonable future he will not be dangerous to himself or to others; and (iii) that the hospital superintendent acted arbitrarily in refusing to recommend his unconditional release. ${ }^{215}$ The Court of Appeals has formulated an exacting test of dangerousness which militates against release: "We think the danger to the public need not be possible physical violence or a crime of violence. It is enough if there is competent evidence that he may commit any criminal act . . ."216 Thus, the court has indicated, by way of dictum, that a prognosis that the accused may engage in forgeries if released justifies his continued detention. Moreover, it is not sufficient for the applicant to prove his case for release by a fair preponderance of evidence. If there is a reasonable doubt that the inmate will be dangerous upon release, the doubts must be resolved against him. . $^{217}$

These doctrinal obstacles loom even larger in view of the difficulties which an indigent inmate encounters in attempting to obtain expert psychiatric testimony which will contradict the opinion of the hospital staff. It is obvious that "the right to bring habeas corpus would be of little value to an indigent person unless expert testimony were ayailable to him to rebut the opinion evidence of the staff of the institution who believed he should be continued in custody." 218 The court has no power to appoint private psychiatrists to assist the applicant; no funds have been allotted for that purpose. ${ }^{219}$ Recognizing these handicaps, the Court of Appeals recently held that a person acquitted by reason of insanity who seeks release from hospital confinement may demand an examination and testimony by psychiatrists attached to the District's Commission on Mental Health. ${ }^{220}$ There has not yet been sufficient experience to determine whether this procedure will provide applicants with the necessary independent psychiatric assistance.

The exacting standards which the Court of Appeals has read into the release provisions have significantly influenced tactics at every stage of a prosecution. Some defendants have elected not to seek a pretrial competency examination, or have resisted a prosecution motion for such a test, because of the fear that the psychiatric report will include an opinion as to their mental condition at

214. The hospital authorities are conservative about recommending release because of concern over public criticism in the event that the defendant commits another offense. The superintendent of St. Elizabeths Hospital has stated that, "In the case of persons who have been arrested, particularly if charged with serious offenses, a greater degree of conservatism must be practiced in the matter of release, in consideration of the attitudes of the public." Overholser, The Present Status of Problems of Release of Patients from Mental Hospitals, 29 Psychiatric Quarterly 372 (1955).

215. Overholser v. Russell, 283 F.2d 195, 197 (D.C. Cir. 1960).

216. Id. at 198; see Goldstein \& Katz, supra note 134, at 235.

217. Ragsdale v. Overholser, 281 F.2d 943, 947 (D.C. Cir. 1960).

218. DeMarcos v. Overholser, 137 F.2d 698, 699 (D.C. Cir. 1943).

219. Ibid.

220. Curry v. Overholser, No. 15,848, D.C. Cir., Nov. 23, 1960. 
the time of the offense, with the consequent possibility of a verdict of not guilty by reason of insanity followed by hospital confinement for an indefinite period. Some baseless insanity pleas may have been eliminated but it is also likely that some defendants in marginal psychiatric categories are discouraged from utilizing the defense. A sociopath, charged with a minor offense, will be advised by counsel in most cases not to invoke the insanity defense, because of the difficulties of securing a hospital discharge. Thus, the net effect of the court's rulings with respect to release may be to confine insanity pleas to grave offenses and the most serious disorders.

\section{The Statistical Effect of the Durham Test}

The statistical evidence available to document the effect of the Durham rule in the District is fragmentary and incomplete. The pre-Durham data is so meager as to foreclose any intensive comparative statistical analysis. To illustrate, there are no reliable figures for comparing the frequency of motions for pretrial mental examinations or pleas of not guilty by reason of insanity before and after July 1, 1954, the date of Durham. There is little doubt that there has been an increase in both pretrial motions and insanity pleas since Durham, but the exact magnitude of the increase is unknown.

The available statistics show the following:

First. Although there has been an increase in the number of acquittals by reason of insanity since Durham, the number of acquittals on this ground is still relatively negligible. According to the Superintendent of St. Elizabeths Hospital, between July 1, 1954, and November 16, 1960, two hundred and twenty-nine persons were found not guilty by reason of insanity and committed to the hospital. ${ }^{221}$ As shown by the chart set out in the margin, ${ }^{222}$ in 1953, the year preceding Durham, 2103 persons were named defendants in criminal proceedings in the District. Only three individuals, or .023 per cent, were found not guilty by reason of insanity. In 1958, five years after Durham, seventeen out of a total of 1714 defendants, or 1.33 per cent, were acquitted on insanity grounds. There was a slight increase in 1959 in the percentage of defendants acquitted on insanity grounds.

In the five years between 1954 and 1959, there were only 90 acquittals because of insanity. During this period approximately 10,000 persons were charged in the District with criminal violations. In other words, approximately 1 per cent of all defendants have been found not guilty for insanity reasons. These figures do not include cases which have been abandoned by the prosecution because the government felt that it could not effectively rebut the insanity defense. But even with appropriate allowance for such cases, it is clear that only a handful of defendants have been exempted from criminal responsibility under the Durham test.

Second. The available evidence is still much too limited to permit any definitive conclusions with respect to the rate of recidivism among persons

221. Overholser, Criminal Responsibility-A Psychiatrist's Viewpoint (unpublished manuscript). 
who have been hospitalized, treated, and then released.223 Of the 90 persons acquitted by reason of insanity between 1954 and 1959, 25 had been granted

222. Disposition of defendants in United States District Court for District of Columbia (Fiscal years 1951-1959):

Insanity Acquittals

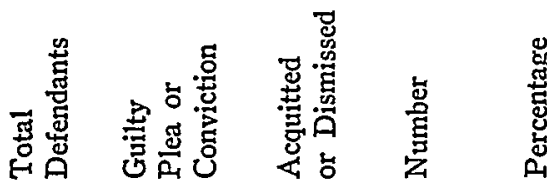

\begin{tabular}{rlrrrr}
\hline 1951 & 1936 & 1374 & 562 & 0 & \\
1952 & 1692 & 1261 & 428 & 3 & .23 \\
1953 & 2103 & 1539 & 561 & 3 & .19 \\
1954 & 1932 & 1427 & 498 & 7 & .49 \\
1955 & 1416 & 1150 & 256 & 10 & .86 \\
1956 & 1650 & 1219 & 415 & 14 & 1.14 \\
1957 & 1517 & 1199 & 311 & 7 & .58 \\
1958 & 1714 & 1265 & 432 & 17 & 1.33 \\
1959 & $1339 * *$ & $* * *$ & $* * *$ & 30 & 2.5 \\
\hline
\end{tabular}

*Percentage of those found to have committed crimes.

**Cases, not defendants. Some cases have several defendants.

***Figures not available.

Sources: The Washington Post \& Times Herald, Aug. 9, 1959, p. E-5, col. 3.

223. Analysis of cases in which defendants were found not guilty by reason of insanity (1954-1959) :

The following table covers all criminal cases since July 1, 1954. Column 1 shows those acquitted of crimes by reason of insanity. Columns 2, 3, and 4 show their status at St. Elizabeths Hospital. Columns 5,6, and 7 show what has happened to those finally released. (Metropolitan Police records only are the basis of columns 5,6, and 7).

\begin{tabular}{|c|c|c|c|c|c|c|c|}
\hline Crime & 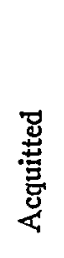 & 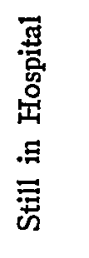 & 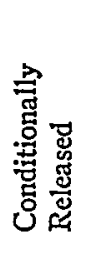 & 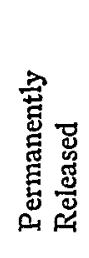 & 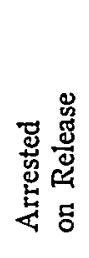 & 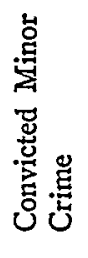 & 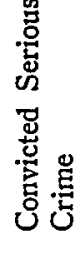 \\
\hline Murder & 16 & 13 & 2 & 1 & 0 & 0 & 0 \\
\hline Assaults & 9 & 4 & 0 & 5 & 0 & 0 & 0 \\
\hline Housebreakings & $13^{*}$ & 7 & 0 & 5 & 0 & 2 & 0 \\
\hline Robbery & $13^{*}$ & 9 & 0 & 3 & 1 & 0 & 1 \\
\hline Thefts & 8 & $4^{* *}$ & 1 & 2 & 0 & 1 & 0 \\
\hline Forgery & 10 & 5 & $\mathbf{0}$ & 5 & 2 & 0 & 1 \\
\hline Other felonies & 9 & 6 & 1 & 2 & 0 & 0 & 1 \\
\hline \multirow[t]{3}{*}{ Municipal Court } & 12 & 10 & 0 & 2 & 0 & 1 & 0 \\
\hline & - & - & - & - & - & - & - \\
\hline & 90 & 58 & 4 & 25 & 3 & 4 & 3 \\
\hline
\end{tabular}

*One person in each category not committed to hospital.

**One died in hospital.

Source: The Washington Post \& Times Herald, Aug. 9, 1959, p. E-5, col. 1. 
an unconditional release from St. Elizabeths Hospital as of August 1959, and four had been conditionally released. Of the 25 permanently released, three have been subsequently convicted of a felony. Four were convicted of a minor offense. Statistics maintained by the hospital show that of the 229 persons committed between July 1, 1954, and November 16, 1960, forty-two were released unconditionally; sixteen were granted conditional releases; and six were released by habeas corpus proceedings. ${ }^{224}$ The data suggests, however, that the term of hospital confinement for persons who have been found not guilty by reason of insanity is not substantially different from the period of imprisonment which would have resulted if the defendants had been found guilty. ${ }^{225}$

\section{ConCLusion}

Durham and its progeny have had a tremendous influence on the administration of criminal justice in the District of Columbia. The statistics, which show only a relatively small number of acquittals by reason of insanity, do not accurately reflect the pervasive awareness of the insanity issue in the District by judges, prosecuting attorneys, and defense counsel. There is today unquestionably greater alertness in the District to an accused's mental condition at every stage of the prosecution than was true before Durham. There are now more frequent pretrial psychiatric examinations; in major criminal cases, a mental examination is becoming routine. Both prosecution and defense have been spurred to more thoughtful trial preparation. Although it is difficult to guage how successful Durham has been in improving the quality of expert testimony, there is no doubt that under Durham, there is greater opportunity to present the jury with information concerning a defendant's background and mental condition. And for the first time attention is being focused on the disposition and fate of a person who is acquitted on insanity grounds.

In retrospect, the Durham decision emerges as the first step in a determined effort by the D.C. Court of Appeals to reform obsolete and inadequate procedures which prevail where insanity is in issue. The court's opinions reflect the conviction that mental disorder plays a more significant role in criminal conduct than is generally recognized. A corollary is that in a number of cases hospitalization and treatment may afford greater protection to the community, and may be more just to the individual, than the usual criminal sanctions.

If the objective of the criminal law were only general deterrence, confinement in a mental institution would serve nearly the same function as imprisonment. The outlook of a mental hospital differs, of course, from that of a prison, but in terms of deprivation of liberty there is little to choose between the maximum security section of a mental institution and a jailhouse. ${ }^{228}$ " $[T]$ he

224. Overholser, Criminal Responsibility-A Psychiatrist's Viewpoint (unpublished manuscript).

225. See The Washington Post \& Times Herald, Aug. 1959, p. E-1, col. 1.

226. See deGrazia, The Distinction of Being Mad, 22 U. CHr. L. Rev. 339, 349-55 (1955). 
prospect of possible life imprisonment in a mental institution . . . may as effectually deter as the prospect of ten years in prison." 227 The objective of temporary protection for the community by immobilizing the offender is secured whether the defendant is incarcerated in a prison or confined in a mental institution.

But the crucial difference between treatment and imprisonment lies principally in the prospects for rehabilitation and reformation of the defendant. In the long run, exponents of the Durham test believe, a defendant who has been treated may prove less likely to commit criminal acts after discharge than if he were imprisoned and released. Given the present state of knowledge with respect to psychiatric treatment of criminal offenders and their postdischarge behavior, it is difficult to prove or to disprove this thesis. But in light of the appallingly high rate of recidivism by released inmates of federal prisonsapproximately 60 per cent are estimated to be repeat offenders-it is clear that even if psychiatric therapy were successful in a modest number of cases, it would represent a noteworthy advance. Durham may thus be viewed as an experiment in collaboration between law and medicine. An extended period, minimally a decade, probably will be necessary before the results can be definitively appraised.

Even if it were true that there were no differences between punishment and treatment in terms of general deterrence, immobilization, and rehabilitation, persuasive reasons would remain for adopting an insanity test which was not irreconcilable with generally accepted medical findings. If a criminal trial is viewed as a symbolic process, appropriate recognition should be accorded for expression of scientific insights. ${ }^{228}$ Durham relieves some of the tension which has existed between the legal and psychiatric view of man's personality.

One difficulty with the Durham approach is that the trial process is, at best, an awkward instrument for segregating those who should be treated from those who should be subjected to punitive-corrective sanctions. Many defendants who might well benefit from therapy are doubtless imprisoned; and, of course, it does not necessarily follow that those acquitted because of insanity by a jury will be amenable to psychiatric treatment. Greater flexibility and use of postconviction disposition procedures-for example, more extensive psychiatric facilities in penal institutions and more liberal transfer of prisoners to hospitals-would ameliorate some of these difficulties. Moreover, Durham and the subsequent appellate court opinions presuppose that treatment will in fact he given to individuals found incompetent to stand trial or acquitted on insanity grounds. Recently, strong criticism has been voiced respecting the ade-

227. $I d$. at 355 .

228. See Arnold, Due Process in Trials, 300 Annals 123, 124-25 (1955) who views the debate between proponents of the Durham rule and its critics as another chapter in the "ever present controversy in American life between those who believe in a secular religion represented roughly by the psychiatrist and those who prefer an expression of moral values in terms of a higher faith." Cf. Katz, Law, Psychiatry, and Free Will, 22 U. CHI. L. REv. 397 (1955). 
quacy of the facilities and the intensity of the treatment which hospitalized defendants receive at St. Elizabeths. ${ }^{229}$ Judicial efforts to reform administration of the insanity defense will be stymied if Congress fails to make provision for adequate facilities and sufficient trained medical personnel.

Having said all of this, it is well to note that Durham and the more than eighty opinions by the Court of Appeals have not disturbed the fundamental ideology of the criminal law. Persons of sound mind convicted of criminal offenses in the District are still subject to the conventional punitive sanctions. Durham does not alter the traditional requirement that the accused be shown by the prosecution to have had a criminal intent. There has been no change in the doctrine that a jury determines whether the accused shall be held criminally responsible by the community. In the end, the enduring significance of the Durham decision may be that it inspired reexamination throughout the country of the responsibility question, and that, together with the subsequent opinions, it furnished an impetus to long-overdue reform of the procedures for dealing with the insanity issue in criminal cases.

229. See The Washington Post \& Times Herald, Sept. 21, 1960, p. A3, co1. 1. 


\section{THE YALE LAW JOURNAL}

\begin{tabular}{lll}
\hline VOLUME 70 & MAY 1961 & NUMBer 6
\end{tabular}

\section{ROBERT E. HudeC \\ Editor-in-Chief}

\author{
NeAle M. Albert \\ LAWRENCE G. GoODMAN \\ David M. TRUBEK \\ JERE A. Young \\ Note \& Comment \\ Editors
}

\begin{abstract}
Burton J. Ahrens
HERSHEL Y. AlLERHAND

Douglas R. Ayer

Cigarles S. Battles, Jr.

HeNRy G. Bisgaier

JOSEPH S. BORUS

Thomas B. Bracken

CarRolL W. BREWSTER

Stephen A. Brown

ALAN M. Dershowttz

JAN DeUTSCH

George B. Driesen
\end{abstract}

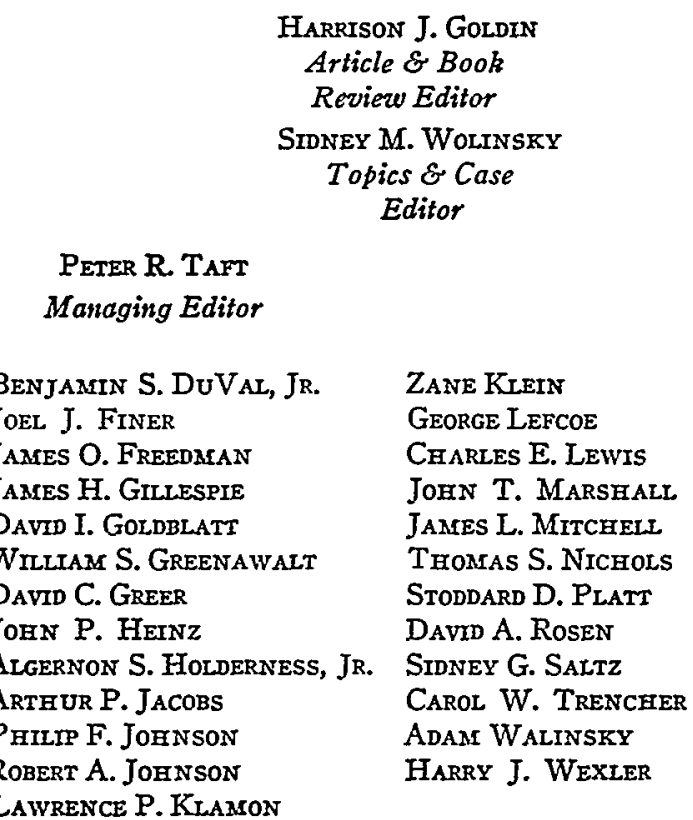

Marie McMagon

Business Secretory

\section{CONTRIBUTORS TO THIS ISSUE}

RoBert B. Stevens. B.A. 1955, B.C.L. 1956, M.A. 1959, Oxford University; LL.M. 1958, Yale University. Assistant Professor of Law, Yale University.

Abe KRASH. A.B. 1946, J.D. 1949, University of Chicago. Member of the District of Columbia Bar. 